REVIEW

\title{
On the advantages and disadvantages of larval stages in benthic marine invertebrate life cycles
}

\author{
Jan A. Pechenik* \\ Department of Biology, Tufts University, Medford, Massachusetts 02155, USA
}

\begin{abstract}
Many benthic marine invertebrates develop by means of free-living, dispersive larval stages. The presumed advantages of such larvae include the avoidance of competition for resources with adults, temporary reduction of benthic mortality while in the plankton, decreased likelihood of inbreeding in the next generation, and increased ability to withstand local extinction. However, the direction of evolutionary change appears generally biased toward the loss of larvae in many clades, implying that larvae are somehow disadvantageous. Possible disadvantages include dispersal away from favorable habitat, mismatches between larval and juvenile physiological tolerances, greater susceptibility to environmental stresses, greater susceptibility to predation, and various costs that may be associated with metamorphosing in response to specific chemical cues and postponing metamorphosis in the absence of those cues. Understanding the forces responsible for the present distribution of larval and non-larval (aplanktonic) development among benthic marine invertebrates, and the potential influence of human activities on the direction of future evolutionary change in reproductive patterns, will require a better understanding of the following issues: the role of macro-evolutionary forces in selecting for or against dispersive larvae; the relative tolerances of encapsulated embryos and free-living larvae to salinity, pollutant, and other environmental stresses; the degree to which egg masses, egg capsules, and brood chambers protect developing embryos from environmental stresses; the relative magnitude of predation by planktonic and benthic predators on both larvae and early juveniles; the way in which larval and juvenile size affect vulnerability to predators; the extent to which encapsulation and brooding protect against predators; the amount of genetic change associated with loss of larvae from invertebrate life cycles and the time required to accomplish that change; and the degree to which continued input of larvae from other populations deters selection against dispersive larvae. The prominence of larval development in modern life cycles may reflect difficulties in losing larvae from life cycles more than selection for their retention.
\end{abstract}

KEY WORDS: Larvae - Life cycle evolution - Marine invertebrates

\section{INTRODUCTION}

The life cycles of most benthic marine invertebrate species include microscopic, free-living dispersive stages that may be feeding (planktotrophic) or nonfeeding (lecithotrophic). In this paper I refer to these free-living developmental stages as larvae. Larvae are morphologically and ecologically distinct from the

\footnotetext{
•E-mail: jpecheni@emerald.tufts.edu
}

adults, they reach the juvenile stage through a conspicuous metamorphosis (Giese \& Pearse 1974, Hill 1991, McEdward \& Janies 1993, Nielsen 1998). Other reproductive patterns lack dispersive larval stages: individuals develop to the juvenile stage entirely within egg masses, egg capsules, or brood chambers, although they often pass through a distinctly larval morphology; I refer to such reproductive patterns as 'aplanktonic.' My definitions thus emphasize where prejuvenile development takes place rather than differences in developmental morphology. Jablonski \& 
Lutz (1983), Grahame \& Branch (1985), McEdward \& Janies (1993), Havenhand (1995), and Levin \& Bridges (1995) discuss alternative terminologies. This paper concerns the forces that may drive reproductive patterns toward larval or aplanktonic development and the constraints that may deter evolution from one pattern to the other.

Of the approximately 40 animal phyla represented in the ocean, only nematodes, chaetognaths, gastrotrichs, kinorhynchs, gnathostomulids, and tardigrades do not include a morphologically or ecologically distinctive, free-living dispersive larval phase in their life history (Strathmann 1985, Levin \& Bridges 1995). Thorson $(1950,1966)$ estimated that 55 to $85 \%$ of all benthic marine invertebrate species produce long-lived planktotrophic larvae (spending weeks to months in the plankton), $5 \%$ produce short-lived planktotrophic larvae (spending hours to days in the plankton), and about $10 \%$ produce lecithotrophic larvae. Even if these estimates should prove excessive in some groups as more life histories are described (Giangrande 1997), it seems safe to say that free-living larval developmentparticularly planktotrophic development-is at least very common within the life cycles of benthic marine invertebrates (Morgan 1995a) and that planktotrophic development has persisted in many clades for hundreds of millions of years (Wray 1995). Because so many species produce dispersive larvae, it is generally assumed that larvae have been selected for (reviewed by de Beer 1958, Underwood 1974, Rex \& Warén 1982, Grahame \& Branch 1985, Hedgecock 1986, Levinton 1995, Wray 1995). However, certain apparent trends in life cycle evolution suggest that larvae have been selectively disadvantageous in many groups.

Although it is not certain whether early larvae were feeding or nonfeeding (e.g. Rouse \& Fitzhugh 1994, Hadfield et al. 1997, Ponder \& Lindberg 1997; reviewed by Nielsen 1998), it is generally believed that free-living larvae of some sort are primitive in marine invertebrate life histories and that the loss of larval stages is a derived condition (e.g. Berrill 1931, Jägersten 1972, Hoagland 1986, Jackson 1986, Strathmann 1986, Emlet et al. 1987, Raff 1987, 1996, Reid 1989, Giangrande et al. 1994, Page 1994, Rawlings 1994. Mooi \& David 1993, Rieger 1994, Strathmann \& Eernisse 1994, Havenhand 1995, Wray 1995, Bhaud \& Duchêne 1996, Byrne \& Cerra 1996, Hart et al. 1997, Ponder \& Lindberg 1997, Nielsen 1998). This assumption is supported by logical argument and intuition, and by some cladistic analyses (e.g. Arndt et al. 1996, Hart et al. 1997, Ponder \& Lindberg 1997), rather than by direct evidence. If external fertilization is primitive, or, as argued by Nielsen (1998), if the ancestral animal life cycle was entirely planktonic, then it is easy to see how morphologically distinctive larvae would be se- lected for as developing embryos became increasingly well adapted to their planktonic habitats (Jägersten 1972, Strathmann 1993, Wray 1995). That aplanktonic development is often associated with substantial behavioral and anatomical modification of adults (e.g. Fretter \& Graham 1994, Byrne \& Cerra 1996, Mooi \& David 1996) also suggests a derived condition in at least many clades, as does the occurrence of what seem to be vestigial larval organs (e.g. the velar lobes of developing gastropods) in the development of many aplanktonic species (Jägersten 1972, Hadfield \& Iaea 1989, Olson et al. 1993, Strathmann 1993, Byrne \& Cerra 1996, Moran in press).

Free-swimming larval stages have clearly been lost one or more times within many groups, including gastropods, echinoderms, and ascidians (e.g. Strathmann 1978, Gallardo \& Perron 1982, Raff 1987, 1996, Wray 1995, Arndt et al. 1996, Poulin \& Féral 1996, Hart et al. 1997, Jeffrey 1997, McEdward \& Janies 1997, Ponder \& Lindberg 1997, Nielsen 1998). Larvae are unlikely to be regained within a clade once lost, particularly when that loss has been accompanied by substantial morphological simplification during embryogenesis (McEdward \& Janies 1997). McEdward (1992, 1995) has documented what appears to be an intriguing exception, the asteroid Pteraster tesselatus, which has apparently evolved a morphologically unique, lecithotrophic larva from a brooding ancestor.

The apparently biased tendency toward the loss of larval stages from life histories in at least some clades suggests that larvae can be a liability, something that selection has acted against. Dispersive larvae are unlikely to be lost in sessile species such as barnacles, but even here there has been selection for reduced dispersal in some cases (e.g. Newman \& Ross 1977, as cited in Jablonski \& Lutz 1983, p 44, Anderson 1994). Particularly among clonal animals selection has clearly favored retaining offspring near the parents (Jackson 1986). Although there is growing understanding about the genetic mechanisms mediating the loss of larval stages, particularly among echinoderms and ascidians (Swalla et al. 1993, Wray 1995, Raff 1996), the pressures selecting for such loss are still unresolved (reviewed by Grahame \& Branch 1985, Emlet et al. 1987. Olson et al. 1993, Havenhand 1995, Wray 1995).

The apparent selection against dispersive larvae in at least some major marine invertebrate groups raises two intriguing questions: (1) To what extent are larvae disadvantageous in marine invertebrate life cycles? and (2) if the direction of evolutionary change has been primarily toward the loss of larval stages, why is larval development still so common? This latter question has been posed explicitly a number of times (e.g. Jackson 1986, Havenhand 1995) but never thoroughly addressed. This review addresses both questions. 
The ancestral nature of larvae has been questioned several times in the past dozen years. Chaffee \& Lindberg (1986) have argued that if early metazoans were small, and if small adults are limited to internal fertilization because of low fecundities, then internal fertilization and brooding may be ancestral in at least some groups, with dispersive larvae representing a derived condition. Assuming that predation and other pressures were similar now and then, production of many, vulnerable larvae would only have become feasible with the advent of large body sizes. This intriguing argument is not convincing, however, as at least some small-bodied invertebrates (e.g. gastropods in the genus Caecum and some small-bodied opisthobranchs) persist even though they release small, longlived, planktonic veliger larvae (Thiriot-Quiévreux 1980, Page 1994, Nielsen 1998). Moreover, planktonic predation pressures may have been far lower 600 or more million years ago than they are now (Nielsen 1998). Even if free-living larvae were feasible only after metazoans attained large body sizes, increased body size does not in itself explain a shift from aplanktonic to planktonic development. Rouse \& Fitzhugh (1994), Wolpert (1994), and Raff (1996) present alternative arguments for the primitiveness of internal fertilization and aplanktonic development. In particular, larvae may have arisen from ancestors with aplanktonic development in some polychaete groups (Rouse \& Fitzhugh 1994, Bhaud \& Duchêne 1996) and in one asteroid species (McEdward 1992, 1995). To date, however, most arguments and evidence favor the evolution of aplanktonic development from ancestors with planktonic development.

The common assumption that larvae are often lost but rarely regained has also been called into question (reviewed by McHugh \& Rouse 1998). Intuitively, it must be easier to lose complex structure than to regain it (Strathmann 1978, 1985). However, McEdward \& Janies (1997) argue that echinoderms may lose dispersive larvae from their life history without major changes in developmental morphology. We might be unable to detect the reacquisition of free-living larvae in such cases, as the returning larvae could be morphologically indistinguishable from the ancestral aplanktonic stage; the apparent bias toward loss of larvae in that group would then be more imagined than real. In consequence, McEdward \& Janies (1997) predict that loss and reacquisition of free-living larvae has occurred more frequently among echinoderms than presently realized. Documenting that such evolutionary swings have occurred will be problematic. However, if shifts between planktonic and aplanktonic development are frequent and fully reversible, we would expect to see more populations in the midst of such shifts. Yet, documented cases of poecilogony are rare (Jablonski \& Lutz 1983, Jablonski 1986, Levin \& Bridges 1995, Chia et al. 1996, Krug 1998); either the variation in reproductive patterns within populations has been poorly sampled, or the shifts between planktonic and aplanktonic modes do not happen frequently.

The loss of larvae may be less readily reversibleand the reacquisition of larvae may be more readily detectable-in gastropods, ascidians, and other groups in which the evolution of aplanktonic development is generally associated with a conspicuous reduction or other modification of larval structure. Gastropod species in the genus Epheria may have regained feeding larvae from ancestors with brooded aplanktonic development, but in this case the full velar structure was never lost by the brooding ancestors so that any reacquisition would simply require redeployment of existing structures (Nielsen 1998). On the other hand, loss of structure need not signal the loss of genes coding for that structure (Raff 1996), making the undetectable reacquisition of larvae theoretically possible even when larval structures have been greatly reduced or entirely lost for millions of years.

If the direction of change has been toward the evolution of larvae in some groups or at some times, then the problem becomes that much more interesting: we must explain not only the transitions that have been clearly biased toward the loss of larval development in some groups (e.g. gastropods, asteroids, and ascidians), but also how selection could simultaneously favor transitions in the opposite direction in selected cases within those groups or for members of some other groups. Molecular studies over the next several years will undoubtedly reveal much about the extent to which larval genomes have merely been temporarily 'silenced' rather than lost on the path to aplanktonic development, and increasingly thorough and convincing phylogenetic analyses may help to resolve controversies about the direction of evolutionary shifts in reproductive patterns within particular groups. In the meantime, it seems safe to assume that the direction of evolutionary change has generally been toward the loss of larval stages, but that shifts in the opposite direction may have occurred at least a number of times in some clades.

It is important, then, to consider both the advantages and disadvantages associated with dispersive larvae that might account for their evolution, maintenance, or loss from life cycles. Because the advantages of larvae have been widely discussed, in this review I focus more on the potential disadvantages of having larvae in the life cycle. I then consider why larval stages typically dominate marine invertebrate life cycles when the direction of evolutionary change apparently favors their loss. These issues are of interest not only for 
understanding the forces that have shaped the present distribution of reproductive patterns among benthic marine invertebrates but also in considering how human activities may be selecting for shifts in reproductive patterns for the future.

'Throughout the paper I refer to 'short-term changes' as those occurring within individual lifetimes and to 'long-term changes' as those occurring over many generations.

\section{ADVANTAGES AND DISADVANTAGES OF DISPERSAL}

The presumed advantages of producing larvae have been discussed for many years, with the emphasis on dispersal and its consequences (e.g. Mayr 1970, Mileikovsky 1971, Crisp 1974, Underwood 1974, Obrebski 1979, Jablonski \& Lutz 1983, Valentine \& Jablonski 1983, Grahame \& Branch 1985, Scheltema 1986, Havenhand 1995, Levinton 1995, Wray 1995). Although considerable dispersal can also be achieved by egg masses and small juveniles in both aplanktonic and planktonic life cycles (Highsmith 1985, Jackson 1986, Scheltema 1986, 1995, Johannesson 1988, Jokiel 1989, O'Foighil 1989, Martel \& Chia 1991, Giangrande et al. 1994, Helmuth et al. 1994, Gebruk et al. 1997), and although free-living larvae do not guarantee extensive dispersal (Burton 1986, Prince et al. 1987, Petersen \& Svane 1995, Parsons 1996), long-lived larval stages confer greater dispersal potential in general (Shuto 1974, Jablonski \& Lutz 1983, Jackson 1986, Emlet et al. 1987, Grantham 1995, Palumbi 1995. Scheltema 1995). Under some current regimes, larvae may be retained near or return to the parental habitat despite a long period in the plankton (Johnson 1971. Knowlton \& Keller 1986, Young \& Chia 1987, Pollock 1992, Shanks 1995, Scheltema et al. 1996), but dispersal away from the original parental habitat, and away from siblings, is probably common (Johnson 1939 , 1974, Scheltema 1971, 1995, Strathmann 1974, 1986. 1993, Jackson \& Strathmann 1981, Knowlton \& Keller 1986, Roughgarden et al. 1988, Morgan 1995a, Lessios et al. 1998). Even short-lived larvae can achieve substantial dispersal from parental populations when water current velocities are high and unidirectional (Dirnberger 1993).

What are the potential benefits of dispersal? Over the short term, exporting offspring from the parental neighborhood avoids competition for resources between parent and offspring (Istock 1967, Havenhand 1995), and can discourage habitat saturation (Holland et al. 1984, Price 1984). Dispersal can also minimize competition for food arnong developing siblings (Economou 1991). It also facilitates rapid range expansion and the colonization of new habitats (Mayr 1970). Dispersal into the plankton has also been viewed as a means of decreasing predation by benthic predators (Pechenik 1979, Strathmann 1985, Lindquist \& Hay 1996); as discussed later, this advantage can be only temporary, as the larvae must eventually descend to the benthos as they begin exploring potential substrates for metamorphosis, and requires that mortality rates from planktonic predators be lower than those brought about by benthic predators (Pechenik 1979).

Having long-lived dispersive larvae in the life cycle should also reduce the likelihood of inbreeding, with its concomitant depressive costs (Jackson 1986, Pusey \& Wolf 1996, Saccheri et al. 1996, Husband \& Schemske 1997. Sakai et al. 1997): larvae disperse away from parents (Thorson 1961, Scheltema 1971, Morgan 1995a, Shanks 1995) and away from siblings (Strathmann 1974), and any given population will receive recruits from many distant populations (Gaines \& Lafferty 1995, Caley et al. 1996). Thus, close relatives are generally unlikely to mate with each other (Jackson 1986).

Over the longer term, extensive dispersal minimizes the likelihood of extinction: individuals have an effective means of escape if local conditions deteriorate. regions experiencing local extinction can be readily recolonized trom distant sources if and when conditions improve, and range extensions can be effected quickly as appropriate new habitat becomes available (Crisp 1974, Brown \& Kodric-Brown 1977, Obrebski 1979, Jablonski \& Lutz 1983, Valentine \& Jablonski 1983, Bryan et al. 1988, Ridley 1996).

Evidence from the fossil record supports the contention that species with high dispersal potential persist longer in geological time than do those with lower dispersal potential (Vermeij 1978, Jablonski \& Lutz 1983, Gili \& Martinell 1994, Ridley 1996). Within the prosobranch gastropod genus Nassarius, for example, no species that lacked planktotrophic larvae (based on protoconch morphology) persisted longer than about 5 million years; in contrast, many species with longlived larvae persisted 15 or even 20 million years (Gili \& Martinell 1994). The potential dangers of defining valid species from fossil shell morphologies are discussed by Hedgecock (1986), and some of the difficulties in deducing developmental mode from early shell morphology are discussed by Lima \& Lutz (1990).

While extensive dispersal can bring both short- and (especially) long-term benefits, there is no convincing evidence or logical argument that larvae have been or are selected for as dispersal agents (Pechenik 1980, Strathmann 1985, 1986, 1993. Hedgecock 1986, Emlet et al. 1987). Indeed, Strathmann (1985) and Hedgecock (1986) see few apparent advantages to extensive dispersal in the short term. Since species that are able to postpone their metamorphosis for the longest periods 
of time tend also to have longer precompetent periods (Pechenik 1980, Jackson \& Strathmann 1981), greater dispersal potential may reflect selection for greater ability to delay metamorphosis, in proportion to the degree of difficulty that larvae will experience in locating suitable juvenile or adult habitat (e.g. Crisp 1974 , Doyle 1975, Obrebski 1979, Pechenik 1980, Bickell \& Kempf 1983). If this is so greater dispersal potential is a byproduct of greater adult habitat patchiness, and dispersal is simply an important consequence of having long-lived larvae in the life cycle.

Indeed, extensive dispersal has a very clear disadvantage: larvae will typically be denied the opportunity to metamorphose into the same habitat in which their parents were able to survive, grow, mature, and reproduce (Caley et al. 1996). Instead, larvae risk being transported to less hospitable environments or being dispersed offshore, never to return (Thorson 1946, Johnson 1960, 1974, Strathmann 1986); parallel arguments have been made for larval fishes (reviewed by Economou 1991). Moreover, extensive dispersal makes species less able to finetune adaptation to local conditions (Strathmann et al. 1981, Bertness 1989, Storfer \& Sih 1998). Particularly when selection coefficients vary markedly among populations, dispersal can be maladaptive and decrease overall fitness (Hedgecock 1986, Storfer \& Sih 1998). These disadvantages apply primarily to species with long-lived larvae: some species with aplanktonic development can also disperse, by rafting, for example (e.g. Highsmith 1985 , Jokiel 1989, O'Foighil 1989, Martel \& Chia 1991, Scheltema 1995), but dispersal is not imposed upon them, and most offspring may well remain in the parental habitat.

Larvae of many, perhaps most, benthic species, have 2 characteristics that will at least partially compensate for the likelihood of dispersal away from the favorable natal habitat. First, larvae of many species do not metamorphose at a particular age or size, but rather metamorphose in response to particular environmental cues, often chemical or physical cues associated with conditions especially appropriate for the juvenile (Thorson 1950, Scheltema 1961, Burke 1983, Hadfield 1986, Pawlik 1990, Morse et al. 1994). Larvae of some species, for example, metamorphose in response to chemical cues associated with a particular prey species (e.g. Hadfield \& Scheuer 1985, Lambert et al. 1997). For sedentary or sessile organisms, like barnacles, oysters, and tube-dwelling polychaetes, that cue may be associated with adults or juveniles of the same species (e.g. Knight-Jones 1953, Hidu 1969, Highsmith 1982 , Yule \& Crisp 1983, Jensen \& Morse 1984, Pearce \& Scheibling 1990, Toonen \& Pawlik 1996, Bryan et al. 1997), a relationship with obviously favorable reproductive consequences. Such selective metamorphosis is presumed to be adaptive, but the benefits have rarely been quantified. The clearest evidence for a relationship between selective metamorphosis and its postmetamorphic benefits is given by Olson (1983) for the colonial ascidian Didenmum molle and by Stoner et al. (1996) for the queen conch, Strombus gigas, but more studies of this sort are clearly needed.

In the absence of specific environmental cues, larvae can generally postpone their metamorphosis-and prolong larval life-for hours, days, or even weeks or months in some species (reviewed by Pechenik 1990. Morgan 1995a), increasing the likelihood that the larvae will eventually metamorphose into an appropriate habitat. This combination of selective metamorphosis and the capacity of competent larvae to delay metamorphosis has been demonstrated for some species in most marine groups, including sponges, anthozoans, scyphozoans, trematode flatworms, turbellarian flatworms, polychaetes, bivalves, gastropods, chitons, crustaceans, echinoids, ascidians, and even coral reef fish (O'Connor 1991, Harms 1992, Harvey \& Colasurdo 1993, Boettcher \& Targett 1996, Harvey 1996, Lasker \& Kim 1996, Weber \& Epifanio 1996, Cowen \& Sponaugle 1997, Fitzgerald et al. 1998, Gebauer et al. 1998; older literature reviewed by Pechenik 1990).

On the other hand, the substratum specificity for metamorphosis that may partially compensate for dispersal away from adult habitat may create several problems that have rarely been discussed or investigated. For example, preferential metamorphosis in response to very specific habitat cues can potentially limit juveniles to suboptimal habitats. Juveniles and adults of some sedentary species might be better able to survive and grow, or might leave more offspring, in some habitats and microhabitats other than those in which they are found, but be excluded from living in those habitats by a narrow responsiveness of larvae to environmental cues. Juvenile queen conch, Strombus gigas, for example, can grow very well on certain algal substrata that induce few or no larvae to metamorphose (Stoner et al. 1996), a possible example of larval pigheadedness: an overly narrow response to environmental cues potentially limits juvenile or adult success. Related phenomena have been reported among insects, with adults sometimes failing to oviposit on suitable food plants because those plants lack the chemical cues required to trigger oviposition (Bernays \& Chapman 1978, Fox \& LaLonde 1993), More examples of larval pigheadedness will probably be found among marine invertebrates once they are sought.

A related phenomenon has been described for 2 coral reef fish species on the Great Barrier Reef, Pomacentrus amboinensis and Dascyllus aruanus. Larvae of both species apparently recruit to the coral Pocillopora damicornis to such a degree immediately upon enter- 
ing the particular lagoon studied that the best habitat, located more centrally in the lagoon, remains uncolonized (Jones 1997). In this situation adult fitness is potentially reduced by a rapid response to a particular chemical cue, rather than by a response to the 'wrong' cue. Marine invertebrates with planktonic larvae are potentially subject to the same effects.

The impact of larval pigheadedness and related phenomena is potentially reduced if larvae become less selective with age. Such declining sensitivity has been documented for larvae of some (Pechenik 1990, Gibson 1995, Jarrett 1997) but not all (e.g. Toonen \& Pawlik 1994, Plaut et al. 1995) species. On the other hand, postmetamorphic growth rates and competitive abilities can be markedly reduced as metamorphosis is delayed (reviewed by Pechenik 1990, Pechenik et al. 1998), so that older, less selective larvae may be less likely to survive to reproductive maturity following metamorphosis. This is discussed more fully later in this paper,

Another potential disadvantage of metamorphosing in response to particular chemical cues, or even simply being induced to explore substrates by those cues (Coon et al. 1990, Zimmer-Faust \& Tamburri 1994), is that predators can potentially mimic the cues and induce larvae to metamorphose under false pretences. I do not know of any examples of this in the marine invertebrate literature, but the widespread responses of larvae to specific chemical signals certainly opens up that possibility. Examples of related subterfuges among insects include the mimicking of female firefly flash patterns by different species of photurid fireflies (Lloyd 1975) and the mimicking of female moth sex pheromone odor by bolas spiders (Stowe et al. 1987), with predation as a consequence in both cases. Marine species most likely to prompt the evolution of such chemical subterfuge by potential predators would be those with large-bodied larvae or rapid postmetamorphic growth.

A similar phenomenon has been described for larvae of the barnacle Balanus balanoides by Holland et al. (1984). When slates were coated with a thin layer of oil from a natural oil seepage, more larvae metamorphosed in response to the oil than onto control pieces of slate. Presumably some component of the oil mimics, at least partially, the natural chemical cue inducing metamorphosis. Similarly, cyprids of the barnacle Balanus glandula were often induced by substrate cues into metamorphosing preferentially into regions of the intertidal zone least likely to support their survival to adulthood (Strathmann et al, 1981). These two examples demonstrate the potential of marine invertebrate larvae to be induced by chemical cues into metamorphosing into disadvantageous circumstances.
Finally, resistance to temperature and salinity stress can vary during development (e.g. Costlow et al. 1960, 1966, Bigford 1977, Bambang et al. 1995, Anger 1996, Sulkin et al. 1996). When larval tolerance to physiological stress exceeds that of the juveniles, larvae may metamorphose into habitats that do not support juvenile survival. For example, megalopae of the Dungeness crab, Cancer magister, survive temperatures between 14 and $22^{\circ} \mathrm{C}$ very well, but $3 \mathrm{rd}$ crab juveniles die at $22^{\circ} \mathrm{C}$ in consequence, megalopae metamorphosing within the warm waters between British Columbia and Vancouver Island are unlikely to reach adulthood (Sulkin et al. 1996). Similarly, larvae of the brackish water crab Rhithropanopeus harrisii can develop at salinities well above those at which adults are found (Costlow et al. 1966).

Selective metamorphosis and the ability of larvae to postpone metamorphosis in the absence of appropriate triggering cues may partially compensate for the negative effects of dispersal away from favorable habitat (Thorson 1950, 1966). However, not all larvae will survive to become metamorphically competent, and not all that survive will eventually encounter appropriate cues or metamorphose into appropriate habitats. Minimizing dispersal from the natal population could thus be a major selective force acting to rid life cycles of free-living larvae. The disadvantages of long-distance dispersal are best avoided by not producing larvae, or by producing larvae that metamorphose almost as soon as they are released into the plankton (Jackson 1986, Olson \& McPherson 1987, Young et al. 1988, Davis \& Butler 1989, Stoner 1990, Bhaud \& Duchêne 1996, Turon \& Vázquez 1996).

\section{ENERGETIC ADVANTAGES AND DISADVAN- TAGES OF PRODUCING LARVAE}

Larvae might be selected for if they cost less to produce, or if planktonic development produces the greatest number of offspring surviving to reproduce per unit of invested energy (Morgan 1995a). Since planktonic larvae-particularly planktotrophic larvae-often derive from small eggs (Vance 1973, Havenhand 1995, Levin \& Bridges 1995, but see Byrne \& Cerra 1996 and Giangrande 1997), larval production could require a lower total energy investment than that required by alternative reproductive patterns (Vance 1973, Menge 1974, Gallardo \& Perron 1982). However, selection for larvae based on energy considerations has been difficult to demonstrate. For one thing, the extent to which maximizing the efficiency of energy investment has played a major role in life-history evolution is not always clear (Underwood 1974, Pechenik 1980). Moreover, an investment in planktonic development does 
not necessarily carry a smaller cost (reviewed by Grahame \& Branch 1985, Strathmann 1985, Levin \& Bridges 1995). Indeed, Crisp (1974) and Chia (1974) suggested that total reproductive expenditure might be greater for species with planktotrophic development than for those with aplanktonic development, because of the much larger fecundities associated with the planktotrophic mode. Some data support this idea of a greater cost for larval production (e.g. Grahame 1977, Todd 1979), while other data indicate that total energy investment is comparable regardless of reproductive mode (Grahame 1982).

In short, then, it is difficult to argue convincingly that larvae have been selected for or against on the basis of short-term advantages or disadvantages associated with energy efficiency or dispersal. In the next sections I argue that larvae may in fact be generally disadvantageous in benthic marine invertebrate life cycles, and suggest that their persistence might reflect causes other than natural selection.

\section{Relative susceptibility to environmental stress}

Species with free-living larvae would be at a disadvantage if larvae are more susceptible than encapsulated or brooded individuals to environmental stress. Major environmental stresses to which developmental stages are potentially exposed include bacterial and viral infection, thermal stress, salinity stress, low oxygen concentrations, chemical pollution, and ultraviolet (UV) irradiation (reviewed by Pechenik 1987, Morgan 1995a, Cohen \& Strathmann 1996, Rawlings 1996). The influence of pollution and UV stress is discussed in a later section, as susceptibility to these stresses may influence future evolutionary trajectories but is unlikely to account for the present distribution of larval and aplanktonic developments.

The relative susceptibilities of free-living larvae and encapsulated or brooded individuals to microbial infection has not been well documented, although individuals in both categories are clearly vulnerable to fungal, protozoan, and bacterial infection (reviewed by Pechenik 1979). Developmental stages are also susceptible to fluctuations in salinity and temperature (Pechenik 1987, Richmond \& Woodin 1996), but again, it is not clear that free-living larvae are more susceptible than encapsulated or brooded embryos to such stresses. For the few gastropod and polychaete species that have been studied to date, egg capsules and egg masses were found to be permeable to water and salts (Galtsoff et al. 1937, Carriker 1955, Pechenik 1982, 1983, Eyster 1986, Medernach 1995, Bhaud \& Duchêne 1996, Woods \& DeSilets 1997). For example, rapid declines in ambient salinity are accompanied by rapid declines in the osmotic concentration of intracapsular fluid for the prosobranch gastropod Nucella lapillus (Pechenik 1983); encapsulation therefore does not spare embryos exposure to salinity fluctuation in that species. Similarly, changes in external salinity effect rapid changes in salinity within jelly masses of the polychaete Eupolymnia nebulosa (Medernach 1995). On the other hand, encapsulated embryos of several gastropod species survived exposure to salinity stress far better than embryos exposed to the same magnitude of salinity stress after being removed from their capsules or egg masses (Pechenik 1982, 1983, Woods \& DeSilets 1997). Thus, encapsulation can protect developmental stages from salinity stress even when the capsules and egg masses are permeable to salts and/or water; protection is probably achieved by slowing the rate of salinity change (Pechenik 1983, Woods \& DeSilets 1997).

Additional laboratory studies are required to determine how widespread these protective benefits of encapsulation are. However, the results of laboratory experiments comparing embryonic and larval tolerances of salinity and other stress factors may mislead us about the relative susceptibilities of embryos and larvae in the field: encapsulation potentially imprisons embryos in stressful situations that free-living larvae can avoid by passive dispersal or active vertical migration (Carriker 1951, Richter 1973, Pechenik 1979, 1983, Heslinga 1976, Pennington \& Emlet 1986, Sulkin et al. 1983, Forward 1985). Encapsulating structures may in fact increase exposure to osmotic stress (Carriker 1955, Gibbs 1968, Pechenik 1982, 1983, Richmond \& Woodin 1996, Woods \& DeSilets 1997), desiccation stress (Kohn 1961, Spight 1975, 1977, Pechenik 1978), and oxygen deprivation (Perron \& Corpuz 1982, Chaffee \& Strathmann 1984, Cohen \& Strathmann 1996, Lee \& Strathmann 1998). The degree to which developing embryos are protected from these and many other stresses may depend more on where parents attach capsules and egg masses than on the properties of encapsulating structures per se (Spight 1977, Pechenik 1978, Biermann et al. 1992).

Although brooding is typically assumed to confer greater safety (reviewed by Emlet et al. 1987, Levin \& Bridges 1995), even less is known about conditions within brood chambers than about conditions within egg masses and egg capsules. Morritt and Spicer (1996) have shown that the intertidal amphipod Orchestia gammarellus maintains the osmotic concentration of fluid within its brood chamber within tight limits in the face of large declines in external salinity; I know of no similar studies on fully marine species, nor of any data on the degree to which the brood chambers of marine species are accessible to water-borne pollutants. Developmental mortality within brood chambers 
of the holothurian Leptosynapta clarki can be remarkably high (up to $100 \%$ ), but the source of that mortality has not yet been determined (Sewell 1996). Similarly, the number of embryos brooded by the asteroids Leptasterias tenera and Asterina phylactica can decline dramatically during development, although the source of those losses is again unclear (Hendler \& Franz 1982, Strathmann et al. 1984). With respect to both survival rate and lifespan, Medeiros-Bergen \& Ebert (1995) could find no apparent advantage of brooding in two brittlestar species.

In summary, the extent to which free-living larvae and encapsulated embryos differ in their vulnerability to environmental stress is not clear. More data are needed concerning (1) the incidence of microbial infection in free-living larvae and encapsulated and brooded embryos; (2) the permeability properties of encapsulating structures and brood chambers to water, salts, and oxygen, and the extent to which capsules, egg masses, and brood chambers are exposed to salinity or low-oxygen stress in the field; and (3) the relative sensitivity of embryonic and larval stages of particular species to particular stresses.

\section{INFLUENCE OF LARVAL EXPERIENCE ON POST- METAMORPHIC PERFORMANCE}

Free-living larvae can also be disadvantageous in more subtle ways if stresses experienced during larval life decrease postmetamorphic performance. Such effects have now been documented for a number of species from several phyla (Pechenik et al. 1998). Starving the larvae of the slipper shell snail, Crepidula fornicata, for 3 to $5 \mathrm{~d}$ either before or after they became competent to metamorphose reduced the average growth rates of well-fed juveniles significantly for at least the first 3 to $4 \mathrm{~d}$ after metamorphosis (Pechenik et al., 1996a, b). Juvenile growth rates were significantly reduced even when larvae were not starved, but only subjected for 2 to $3 \mathrm{~d}$ to a greatly reduced food concentration (Pechenik et al. 1996b). Similarly, not feeding the facultatively planktotrophic larvae of the opisthobranch gastropod Phestilla sibogae lengthened the time between metamorphosis and reproductive maturity (Miller 1993). Thus, to the extent that larvae are food-limited in the field IOlson \& Olson 1989, Fenaux et al. 1994), even short periods of reduced food availability during larval life may limit postmetamorphic rates of growth or development, potentially increasing the period of maximum vulnerability to predators, increasing the time to reproductive maturity, or reducing competitive ability.

Similar effects have been found in the laboratory when larvae, especially lecithotrophic larvae, of vari- ous species were forced to delay their metamorphosis (Highsmith \& Emlet 1986, Woollacott et al. 1989, Orellana \& Cancino 1991, Pechenik et al. 1993, Wendt 1996). In 14 experiments conducted with the bryozoan Bugula stolonifera, for example, prolonging larval life by as little as $10 \mathrm{~h}$ at $20^{\circ} \mathrm{C}$ led to significantly reduced rates of colony development; in some experiments, the effects were seen when larval life was prolonged by only 6 to 8 h (Woollacott et al. 1989). Similar results have been reported for Bugula neritina by Wendt (1996), who showed that the slower rate of colony development owes to significantly reduced size of the juvenile feeding structure, the lophophore. Delaying metamorphosis of the barnacle Balanus amphitrite by $3 \mathrm{~d}$ at $28^{\circ} \mathrm{C}$ also caused a significantly reduced rate of juvenile growth (Pechenik et al. 1993). Delaying metamorphosis of planktotrophic polychaete larvae, Hydroides elegans, by at least 3 d reduced both juvenile survival and juvenile growth rate, whether larvae were fed during the delay period or not (Qian \& Pechenik 1998). For B. neritina, the effects of delayed metamorphosis persisted for at least $2 \mathrm{wk}$ in field transplants, reducing both the rate of colony development and reproductive output (Wendt 1998). In addition, long delay periods for some lecithotrophic larvae (e.g. the asteroid Ophidiaster granifer) can result in abnormal juveniles (Yamaguchi \& Lucas 1984) or smaller average sizes at metamorphosis (Yamaguchi \& Lucas 1984). Delaying metamorphosis, previously considered as purely advantageous in promoting placement of juveniles into appropriate habitat, can clearly compromise the ability of juveniles to compete for space, heighten vulnerability to predators, and possibly reduce tolerance to physical stress and increase postmetamorphic mortality (Highsmith \& Emlet 1986, Pechenik 1990, Pechenik \& Cerulli 1991, Pechenik et al. 1996b); the potential advantages of a prolonged stay in the plankton beyond the onset of metamorphic competence may thus never be fully realized.

To date, documented effects of food limitation and delayed metamorphosis on juvenile performance have been mostly short term. Long-term studies, such as those of Miller (1993), may reveal additional effects on maturation periods and total reproductive output in some species. Also, other stresses experienced by larvae-short-term pollutant stress, for example-may be found to produce similar effects on postmetamorphic performance once they are sought.

Correlations between larval experience and postmetamorphic performance have rarely been examined in field populations. The growth potential of recently metamorphosed acorn barnacles, Semibalanus balanoides, has been shown to differ significantly among groups of larvae recruiting on different days at a particular site in Massachusetts (Jarrett \& Pechenik 1997). 
These results are consistent with the hypothesis that larvae of this species delayed their metamorphosis more frequently later in the season, or that they experienced substantial variation in food quality or quantity at different times during the reproductive season. Alternatively, the results could reflect recruitment from genetically and physiologically distinct adult populations at different times during the breeding season (e.g. Watts et al. 1990).

In summary, larval experience has the potential to play subtle but important roles in reducing postmetamorphic recruitment success in at least some species. Unfortunately, there are as yet no data on the extent to which brooding or encapsulation protects developing embryos from this effect. Stresses experienced within capsules and brood chambers may also affect postemergence growth, survival, maturation time, or fecundity, but the necessary studies have not yet been done. It is not yet clear, then, that free-living larvae are uniquely susceptible in this regard.

\section{RELATIVE SUSCEPTIBILITY TO PREDATION}

Extent of planktonic mortality. Few of the phenomenal number of eggs that are fertilized by species producing planktonic larvae ever reach adulthood (Thorson 1950). Thorson (1950) concluded that most of this implied loss during development was due to planktonic predation, and that view has changed little over the past nearly $50 \mathrm{yr}$. However, many unresolved questions remain about exactly how much mortality occurs in the plankton and the source of that mortality, as discussed in several extensive reviews (Hines 1986, Young \& Chia 1987, Rumrill 1990, Morgan 1995a). In particular, what proportion of the total pre-juvenile loss is due to other factors such as permanent dispersal away from favorable sites, or developmental defects inherent in the larvae (Heath 1992)? How does vulnerability to predators change as larvae grow? What proportion of mortality occurs during planktonic dispersal and what proportion occurs during benthic substrate exploration? How much of the total mortality occurs between the time of metamorphosis and the time at which individuals have grown to a size easily sampled by marine ecologists?

Direct evidence of predation on larvae includes finding larvae in the guts of predators and documenting predation in laboratory studies. In at least some cases, estimated high predation rates on larvae may be artifacts of field sampling or laboratory methodologies (Johnson \& Brink 1998). In addition, direct observations of planktonic mortality have been made for some ascidian species living in clear waters and producing large, conspicuously colored larvae that are competent to metamorphose immediately upon their release into the plankton (Olson \& McPherson 1987, Davis \& Butler 1989. Stoner 1990). Predation rates observed in the field were remarkably high, with as many as $87 \%$ of larvae being eaten within only 2 min of release (Olson \& McPherson 1987). It seems unlikely that most invertebrate larvae suffer such high predation rates, however; at such rates we would be left with only a single larva within $15 \mathrm{~min}$ for every 100000 larvae released! Direct observation of larval mortality may be misleading: possibly SCUBA divers attract predators to the area. In any event, direct observation is not possible for the larvae of most species, as they are microscopic and require at least days or weeks before even becoming competent to metamorphose.

Other indirect evidence certainly points to substantial predation in the plankton: predation has apparently been substantial enough to select for specific timing of adult spawning behavior (reviewed by Forward et al. 1982, Morgan 1995b, Lindquist \& Hay 1996, Morgan \& Christy 1997) and the evolution of behavioral (Young \& Chia 1987, Forward \& Hettler 1992), physical (reviewed by Morgan 1995a), and chemical defenses against predation (Lindquist \& Hay 1995, 1996, Harvell et al. 1996, Uriz et al. 1996; reviewed by Young \& Chia 1987, Morgan 1995a). As Morgan (1995a) points out, however, we cannot be certain that such traits are adaptive unless we can determine that they effectively increase adult reproductive success.

Most mortality estimates for planktonic larvae (reviewed by Strathmann 1985, Hines 1986, Rumrill 1990, Morgan 1995a; see also Ayers 1956) are understandably indirect, made by comparing concentrations of larvae in different stages of development, comparing estimates of fecundity and recruitment, and occasionally by following cohorts over time. Interpreting such data is fraught with difficulties (Hines 1986, Young \& Chia 1987, Rumrill 1990, Morgan 1995a); in particular, it is usually difficult to distinguish between losses from predation and losses from other sources, including dispersal out of the sampling area (Thorson 1950, Roughgarden et al. 1988, Hill 1991), vertical migration of larvae to different depths (Cronin \& Forward 1986), metamorphosis to the benthos, and loss due to developmental defects inherent in the larvae (Heath 1992). These and other difficulties are usually ignored, so that although losses are certainly high, the extent and sources of those losses, and when they occur, are not generally known.

Size-dependent vulnerability to planktonic predators. It is commonly assumed that vulnerability to predators declines with increasing larval size. However, the relationship between larval size and vulnerability to predators has not been well explored for marine invertebrates. Most data are based on labora- 
tory experiments with particular predators of particular sizes confined with prey in small volumes of water (reviewed by Rumrill 1990). As discussed below, the relationship between larval size and vulnerability to predators may be more complicated than is generally appreciated.

Some of the most sophisticated studies and complex models of changing vulnerability to predators are described in the fisheries literature (e.g. Bailey \& Houde 1989, Fuiman 1989, 1994, Cowan \& Houde 1992, 1993, Heath 1992, Litvak \& Leggett 1992, Pepin \& Shears 1995, Cowan et al. 1996, Elliott \& Leggett 1996, Gleason \& Bengston 1996, Letcher et al. 1996. Luo et al. 1996, Olson 1996). In some of these studies greater-sized larvae escaped (e.g. Fuiman 1994), while in other cases predation fell most heavily on the largest individuals (e.g. Litvak \& Leggett 1992, Cowan \& Houde 1993, Pepin \& Shears 1995). In studies on Inland silverside larvae (Menidia beryllina), striped bass and white perch preyed preferentially on the smallest larvae, while bluefish preyed preferentially on the largest larvae (Gleason \& Bengtson 1996). While larger larvae may be too big for some predators to ingest whole and be better able to detect predators and evade attack, larger larvae may also be more conspicuous to visual predators (e.g. Fuiman 1989), and those that swim more rapidly because of their larger size produce higher potential encounter rates between predator and prey, particularly if the predator is slow moving (Bailey \& Houde 1989, Fuiman 1989, 1994, Cowan et al. 1996, Letcher et al. 1996). Moreover, prey in some instances become less vulnerable to some predators but more vulnerable to other predators as they grow larger (e.g. Gleason \& Bengston 1996), and in some cases prey behaviors that decrease vulnerability to one set of predators increase vulnerability to another set of predators (Crowder et al. 1997). Finally, extensive predation may take place early in development, before larvae have been able to grow large enough to achieve any protective benefit from a more rapid growth rate or larger size (e.g. Rice et al. 1993, Cowan et al. 1996). Thus, the effects of faster growth and larger size on larval mortality in the field are remarkably uncertain for larval fishes; the effects will vary according to the size and behavioral characteristics of the predators and the prey (Bailey \& Batty 1983, Cowan \& Houde 1992, Yamashita et al. 1996), prey concentration (Luo et al. 1996), and availability of alternative prey (Pepin \& Shears 1995, Fortier \& Villeneuve 1996). The extent to which these factors influence predation on invertebrate larvae in the field is even less certain, and remains to be determined. It may be that invertebrate larvae remain fully vulnerable to planktonic predators throughout their planktonic lives; they may even become more vulnerable once they exceed a particular size, by becoming more conspicuous to predators or through an effect of increased swimming speed on the frequency of predator/prey encounters.

Vulnerability at the time of substrate exploration. Although planktonic mortality must be substantial, larvae may be at far greater risk during substrate exploration than during the planktonic period (MacGinitie 1934, Carriker 1955, Pechenik 1979, Strathmann 1985, 1986, Hines 1986, Emlet et al. 1987, Morgan 1995a).

In a direct observation of planktonic mortality in the field, $86 \%$ of ascidian larvae lost to predation were killed by benthic, as opposed to planktonic, predators (Stoner 1990). The apparently widespread ability of larvae to delay metamorphosis in the absence of suitable substrate (Pechenik 1986b, 1990, Scheltema 1995) implies that predation in the plankton is less critical than the advantages of eventually locating habitat appropriate for subsequent juvenile development. The widespread distribution of mixed development, in which embryos spend days or weeks developing within masses, capsules, and brood chambers before emerging into the plankton for another several weeks or more as larvae, also supports the proposition that the plankton may be safer for larvae than the benthos (Pechenik 1979): the advantages of mixed development are easily recognized if mortality in the plankton is lower than what would be experienced by helpless embryos drifting over the bottom (Pechenik 1979). Similarly, the apparent rarity of free-living demersal (benthic) larvae in invertebrate life histories may reflect the relative safety of planktonic versus benthic habitats (McEdward \& Janies 1997). The potential impact of benthic predators during larval substrate exploration may be augmented by slow larval swimming speeds (Chia et al. 1984), which can confine larvae through hydrodynamic forces to the few millimeters above the substrate (Jonsson et al. 1991, André et al. 1993).

Mortality from benthic carnivores, benthic suspension-feeders, and benthic deposit-feeders must be extremely high (Thorson 1946, 1966, Young \& Chia 1987, Rumrill 1990, André et al. 1993, Tamburri \& Zimmer-Faust 1996, Naylor \& McShane 1997, Moksnes et al. 1998), although more carefully designed studies are required to fully quantify the effects (Mileikovsky 1974, Young 1990, Morgan 1995a). The key issue now is whether exploring larvae or newly metamorphosed juveniles are more susceptible to benthic mortality than individuals newly emerged from egg cases or brood chambers, as discussed in the next section.

Relationship between reproductive pattern and vulnerability to benthic predators. Clearly, larvae must suffer considerable mortality both in the plankton and during the time of substrate exploration; a species will avoid both mortality sources by eliminating larvae 
from the life history. On the other hand, if there is an 'escape in size' from benthic predators, having planktotrophic larvae in the life history could improve juvenile survival by allowing growth to a large size before metamorphosis takes place. Newly metamorphosed invertebrate juveniles experience dramatically high mortality from a variety of predators (reviewed by Thorson 1961, Gosselin \& Qian 1997, Hunt \& Scheibling 1997, Ray-Culp et al. 1997). Metamorphosing at larger sizes might reduce postmetamorphic mortality, to the extent that juveniles are protected against predation by larger body size.

Although individuals within egg capsules and brood chambers may in some cases compete for food and consequently emerge at very different sizes (Spight 1976, Rivest 1983, Byrne 1996, Byrne \& Cerra 1996), the supply of food to individual eggs, capsules or egg masses is fixed by the parent (Rivest 1983, Hoagland 1986). In contrast, free-living, feeding larvae can potentially take advantage of phytoplankton productivity and grow to a larger size before exploring substrates or metamorphosing. Species most likely to benefit are those in which juvenile growth rates are rapid and vulnerability to predators declines markedly with increased juvenile size. We can explore this issue in 2 ways: (1) is there an escape in size for benthic juveniles? and (2) are planktotrophic larvae larger at metamorphosis than individuals of closely related species when they emerge from benthic encapsulating structures or brood chambers?

Is there an escape in size for juveniles, and if so, in what size range does it occur? In some studies with snails, lobsters, crabs, and barnacles, larger individuals experienced less predation than smaller individuals, but even the largest individuals always remained somewhat vulnerable (Palmer 1990, Wahle \& Steneck 1992, Sousa 1993, Moksnes et al. 1998). In other cases, larger size increased vulnerability to some predators, probably by increasing the ease with which the predators could manipulate the prey (Sousa 1993, Osman \& Whitlatch 1996). However, prey were at least $5 \mathrm{~mm}$ long in most of these studies, well above the size at which most invertebrate larvae metamorphose. In a population of the barnacle Balanus glandula, mortality during the first $24 \mathrm{~h}$ after attachment (30 to $40 \%$ ) was 1.5 to 6 times greater than that for the second $24 \mathrm{~h}$, and the extent of mortality was not related to size at the time of attachment (Gosselin \& Qian 1996). Indeed, extensive mortality during the first few days or weeks is likely to be the rule for most invertebrates (Gosselin \& Qian 1997, Hunt \& Scheibling 1997, Ray-Culp et al. 1997). Walters and Wethey (1996) report mortality rates up to $44 \%$ per day for the bryozoan Schizoporella errata, and $37 \%$ per day for juveniles of Balanus spp. Thorson (1966) found that about $98 \%$ of newly meta- morphosing benthic animals were killed before reaching a size of $2 \mathrm{~mm}$. To the extent that there is an escape in size then, that escape seems available only after juveniles have had time to grow substantially larger than the size at which larvae typically metamorphose. However, further studies relating size to predator vulnerability for newly metamorphosed individuals are needed.

As mentioned earlier, delaying the metamorphosis of species with lecithotrophic larvae can result in smaller juveniles at metamorphosis (e.g. Yamaguchi \& Lucas 1984, Wendt 1996); in such cases, to the extent that larger size at metamorphosis reduces predation on early juveniles, prolonging the life of lecithotrophic larvae will be disadvantageous, not advantageous.

Similarly, there is no convincing evidence that planktotrophic larvae are generally larger at metamorphosis in comparison with the sizes at emergence for species with aplanktonic development. Data on the sizes at which planktotrophic larvae and brooded or encapsulated individuals enter the benthos are summarized in Table 1. Typically there is considerable overlap in the sizes at which juveniles emerge and larvae metamorphose. For the 4 listed species of Littorina, for example, and for the various Crepidula species, individuals enter the benthos at about the same size whether they derive from free-living larvae or not. These data are surprising in that gastropod larvae of tropical species can achieve far larger sizes before metamorphosing (e.g. Thorson 1961, Scheltema 1971); the limited size ranges tabled here for metamorphosing gastropod larvae must not reflect the functional constraints against large body size associated with larval design that were postulated for ophiuroid larvae by Hendler (1975). Large larval size will be selected against in temperate waters if larger larvae are more vulnerable to planktonic predators. In such a case, maximum larval size could reflect a tradeoff between increased vulnerability to planktonic predators before metamorphosis and reduced vulnerability to benthic predators during substrate exploration and following metamorphosis.

In some invertebrate groups, brooded individuals enter the benthos at a substantially larger size than individuals of related species that develop as planktonic larvae, as seen for ophiuroids (Hendler 1975, 1991) and within the asteroid genus Patiriella (Byrne \& Barker 1991, Byrne \& Cerra 1996). In such cases, if there is an escape in size - if larger juveniles are less vulnerable to predators - the advantage will go to the brooders, not to the species with larvae. Thus larval development may increase vulnerability to predators at the start of juvenile life rather than lessen its impact; there is as yet no indication that larvae typically enter the benthos at larger sizes than brooded or encapsulated embryos 
Table 1 Relationship between developmental mode and size at which juveniles enter the benthos [p: planktotrophic larva, l: lecithotrophic larva, a: aplanktonic (lacking a free-Living larval stage), ae: aplanktonic encapsulated, ab: aplanktonic brooded]

\begin{tabular}{|c|c|c|c|}
\hline Species & evelopmental mode & Size $(\mu \mathrm{m})$ & Reference \\
\hline \multicolumn{4}{|l|}{ Gastropods } \\
\hline Anachis avara & $p$ & 630 & Scheltema (1969) \\
\hline A. translirata & $\mathrm{p}$ & 900 & Scheltema \& Scheltema (1963) \\
\hline Bittium alternatum & $\mathrm{p}$ & $300-350$ & Pechenik (1980) \\
\hline B. reticulatum & $\mathrm{p}$ & 320 & Thorson (1946) \\
\hline Buccinum undatum & a.e & 1000 & Thorson (1946) \\
\hline Cerithiopsis barleei & $\mathrm{p}$ & 640 & Lebour (1937) \\
\hline C. tubercularis & $\mathrm{p}$ & $640+$ & Lebour (1937) \\
\hline Conus abbreviatus & $\mathrm{p}$ & 1120 & Perron (1981) \\
\hline C. rattus & $\mathrm{p}$ & 1350 & Perron (1981) \\
\hline C. textile & $\mathrm{p}$ & 1510 & Perron (1981) \\
\hline Crepidula convexa & $\mathrm{ae} / \mathrm{b}$ & 950 & Hendler \& Franz (1971) \\
\hline C. aculeata & $\mathrm{ae} / \mathrm{b}$ & 840 & Hoagland (1986) \\
\hline C. cerithicola & $a e / b$ & $670-920$ & Hoagland (1986) \\
\hline C. dilatata & $\mathrm{ae} / \mathrm{b}$ & $900-1370$ & Gallardo (1977) \\
\hline C. dilatata & $\mathrm{ae} / \mathrm{b}$ & $1075-1600$ & Chaparro \& Paschke (1990) \\
\hline C. dilatata & $\mathrm{ae} / \mathrm{b}$ & $804-1862$ & Chaparro et al. (1999) \\
\hline Crepidula fornicata & $\mathrm{p}$ & $800-1300$ & Calabrese \& Rhodes (1974) \\
\hline C. fornicata & $p$ & $729-1350$ & Pechenik \& Heyman (1987) \\
\hline Littorina littorea & $\mathrm{p}$ & $350-400$ & Thorson $(1946)$ \\
\hline L. obtusata (= littoralis) & ae & $450-500$ & Lebour (1937), Thorson (1946) \\
\hline Littorina picta & $\mathrm{p}$ & 250 & Struhsaker \& Costlow (1968) \\
\hline L. saxatilus & $a b$ & $<354$ & Lebour (1937), Thorson (1946) \\
\hline Ilyanassa obsoleta(= Nassarius obsoletus) & $\mathrm{p}$ & $550-950$ & Scheltema (1967) \\
\hline Nassarius reticulatus & $\mathrm{p}$ & $720-800$ & Thorson (1946) \\
\hline N. trivittatus & $\mathrm{p}$ & $900-1100$ & Scheltema \& Scheltema (1965) \\
\hline N. vibex & p & $600+$ & Scheltema (1962) \\
\hline Natica pallida & ae & 1700 & Thorson (1946) \\
\hline N. poliana & $\mathrm{p}$ & 1000 & Lebour $(1937)$ \\
\hline Nucella crassilabrum & ae & $825-1300$ & Gallardo (1979) \\
\hline N. emarginata & ae & $900-1800$ & Gosselin \& Chia (1995) \\
\hline Philbertia gracilis & $\mathrm{p}$ ? & 1760 & Lebour (1937) \\
\hline P. linearis & $\mathrm{p}$ & 800 & Lebour (1937) \\
\hline \multicolumn{4}{|l|}{ Rissoa membranacea } \\
\hline Type A & $\mathrm{p}$ & $280-420$ & Warén (1996) \\
\hline Type B & ae & $280-360$ & Warén $(1996)$ \\
\hline \multicolumn{4}{|l|}{ Asteroids } \\
\hline Asterias vulgaris & $p$ & 530 & Emlet et al. (1987) \\
\hline Asterina batheri & $p$ & 800 & Emlet et al. (1987) \\
\hline A. burtoni & $\mathrm{p}$ & 800 & Emlet et al. (1987) \\
\hline A. gibbosa & $a b$ & 1000 & Emlet et al. (1987) \\
\hline A phylactica & $a b$ & 750 & Emlet et al. (1987) \\
\hline A. minor & $\mathrm{p}$ & 700 & Emlet et al. (1987) \\
\hline A pseudoexigua pacifica & $a b$ & 900 & Byrne 1996 \\
\hline Patirella regularis & $\mathrm{p}$ & $410-500$ & $\begin{array}{l}\text { Byrne \& Barker (1991)i } \\
\text { Byrne \& Cerra (1996) }\end{array}$ \\
\hline P. calcar & l & 51.7 & M. Byrne, pers. comm. \\
\hline P. parvivipara & $a b$ & $1000-5000$ & Byrne \& Cerra (1996) \\
\hline P. vivipara & $a b$ & $1500-5000$ & Byrne (1996) \\
\hline \multicolumn{4}{|l|}{ Echinoids } \\
\hline Heliocidaris erythrogramma & 1 & 424 & Emlet \& Hoegh-Guldberg (1997) \\
\hline H. tuberculata & $\mathrm{p}$ & 378 & Emlet \& Hoegh-Guldberg (1997) \\
\hline Anthocidaris crassipina & $\mathrm{p}$ & 314 & Emlet \& Hoegh-Guldberg (1997) \\
\hline Echinometra lucunter & $\mathrm{p}$ & 380 & Emlet et al. (1987) \\
\hline \multicolumn{4}{|l|}{ Ophiuroids } \\
\hline Various species & $p$ & $\begin{array}{c}200-900 \\
\text { (disc diameters) }\end{array}$ & Hendler (1991) \\
\hline Amphioplus abditus & ae & 300 & Hendler (1975) \\
\hline Amphiophiura pachyplax & $a b$ & 900 & Hendler 1991 \\
\hline Amphiopholis japonica & $a b$ & 1200 & Hendler (1975) \\
\hline Astrothorax waitei & $a b$ & 2000 & Hendler (1975) \\
\hline Ophiacantha vivipara & $a b$ & 2500 & Hendler (1975) \\
\hline Ophionotus hexactis & $a b$ & 8300 & Hendler (1975) \\
\hline
\end{tabular}


Larvae are clearly vulnerable to predation while planktonic, while exploring substrates, and as juveniles following metamorphosis, and no evidence exists that larvae take advantage of the potential benefits associated with metamorphosing at sizes large enough to reduce postmetamorphic predation intensity. Loss of larvae from marine invertebrate life cycles could reflect selection by predators, assuming that embryos are safer while developing within capsules or egg masses, as discussed in the next section.

Relative vulnerability of larvae and brooded or encapsulated embryos. To what extent are brooded or encapsulated embryos less vulnerable to predators than free-living larvae? Capsules and egg masses are conspicuous, accessible, and lack physical defenses and escape behaviors. Moreover, they are rarely defended chemically (see Pawlik et al. 1988 and Lindquist \& Hay 1996 for 2 exceptions), possibly because compounds that are effective against predators are likely to be toxic to developing embryos (Orians \& Janzen 1974). There are many reports of intense predation on egg capsules and egg masses by a wide variety of predators (Spight 1977, Brenchley 1982, Rawlings 1990, 1994; reviewed by Pechenik 1979, Eyster 1986). Reports of 50 to $70 \%$ predation are not uncommon. Similarly high predation rates have been reported for demersal egg masses of flounder and other fish species (Bailey \& Houde 1989). Brooded embryos of the holothurian Cucumaria lubrica are preyed on by the amphipod Parapleustes pugettensis (Engstrom 1982).

The question of whether larvae are more vulnerable to predators than encapsulated or brooded embryos remains unresolved. Estimated mortality rates for encapsulated embryos often overlap with those for planktonic larvae (Strathmann 1985, Hines 1986, Rumrill 1990). Similarly, Spight (1975) found that the number of juvenile snails per adult at a site along the Washington coast was similar for species with planktonic and aplanktonic development, suggesting that comparable numbers of fertilized eggs survive to the juvenile stage regardless of developmental mode. Having larvae in the life history may have no net impact on vulnerability to predators.

\section{ACCOUNTING FOR LARVAE IN INVERTEBRATE LIFE HISTORIES}

Clearly there are long-term benefits associated with the dispersal mediated through larval stages. But it is equally clear that dispersal carries numerous shortterm disadvantages, the most obvious of which is the likelihood that larvae will be dispersed away from proven habitat. In addition, larvae face potentially greater exposure to chemical and physical stresses, and only larvae are exposed to both planktonic and benthic predators. When substrate searching begins, larvae are also potentially more susceptible to benthic predators due to small larval size. Substrate specificity for metamorphosis may partially compensate for dispersal away from parental habitat, but larvae then become potentially vulnerable to chemical subterfuge, and postmetamorphic fitness may be reduced if larvae delay metamorphosis for too long while awaiting contact with suitable substratum. Nutrient limitation and other stresses experienced by larvae can also decrease postmetamorphic fitness. In addition, specificity of the metamorphic response can potentially deter the spread of adults into favorable new niches. How can we explain the prevalence of larval development in benthic marine invertebrate life cycles?

Chaotic dynamics in a patchy environment should favor the evolution or maintenance of dispersal (Gallardo \& Perron 1982, Jablonski \& Lutz 1983, Holt \& McPeek 1996). On the other hand, larvae should be lost from life cycles when habitats are so rare and patchily distributed that larvae would have a low probability of encountering them once they have been dispersed away from the parental location (Jablonski \& Lutz 1983, Hoagland 1986). Larvae should also be selected against when planktonic mortality rates are very high (Johst \& Brandl 1997) or when habitat quality varies spatially but not temporally (Holt \& McPeek 1996 , Johst \& Brandl 1997). However reproductive patterns often vary widely among co-occurring species, even within the same genus (e.g. Mileikovsky 1975 , Strathmann 1987, Hart et al. 1997). What selective forces could account for the retention of larvae in some species and the loss of larvae in closely related cooccurring species with similar niches (e.g. species within the gastropod genus Littorina)? It seems unlikely that such co-occurring species experience dramatically different variation in juvenile or adult patch quality, or dramatically different rates of larval mortality in the plankton. A better understanding of when reproductive patterns diverged in related species, geographical distributions at the time of the divergence, and the phylogenetic relationships among the species concerned would help to resolve these issues. But in general it is difficult to argue that dispersal is advantageous in the short term (Strathmann 1986, 1993). As discussed earlier, the documented and potential disadvantages of dispersal are substantial. It seems unlikely that larvae have been selected for directly as dispersal agents (Pechenik 1980, Strathmann 1985, 1986, 1993, Hedgecock 1986, Emlet et al. 1987).

If producing larvae has so many apparent drawbacks and if the direction of evolutionary change has tended generally toward the loss of larval stages from life 
cycles, then why is larval development so common among benthic marine invertebrates, particularly if the Permian-Triassic extinction selected against planktotrophs, as suggested by Valentine (1986)? I consider the following possibilities in sequence:

(1) Species with planktonic larvae may speciate more readily than those with aplanktonic development.

(2) Species with planktonic larvae may better withstand periodic local catastrophes, and so accumulate over time

(3) Opportunities for losing larvae may be limited by developmental, genetic, physiological, or ecological constraints.

Role of differential speciation rates. In the absence of extinction, higher speciation rates for species with larval dispersal could create over time the observed prevalence of this developmental pattern. However, speciation rates are probably lower for species with larvae and higher for species with aplanktonic development (Hansen 1983, Jablonski \& Lutz 1983, Grantham 1995). Species with aplanktonic development are more readily divided into genetically isolated populations, and so are more susceptible to the effects of drift and local selection (Valentine \& Jablonski 1982, Allcock et al. 1997, Hoskin 1997). In contrast, species with long-lived larval stages tend to show less genetic differentiation over long distances (reviewed by Palumbi 1995, Hoskin 1997), although exceptions exist as discussed below. Thus, far from helping to explain the prevalence of larval development, differential speciation rates should instead have increased the proportion of species with aplanktonic modes of development.

Macroevolutionary considerations, the role of extinction, and the constraint of time. To the extent that species with aplanktonic development have smaller geographic ranges and more limited dispersal capability, they should be more likely to become extinct than species with long-lived larvae (reviewed by Jablonski \& Lutz 1983, Grantham 1995, Jablonski 1995, McEdward \& Janies 1997). Over the past 540 million years, there have been at least 12 recognizable extinction events, including five particularly spectacular ones (Jablonski 1995, Sepkoski 1996). The most recent mass extinction took place at the end of the Cretaceous about 65 million years ago. But probably more than $90 \%$ of recorded species extinctions have occurred outside the five major extinction episodes, during periods of so-called background extinction (Jablonski 1995). Certainly there have been adequate opportunities for species selection to have played a role in favoring dispersal capability by selecting against nondispersers, but determining the extent and direction of the effect is problematic.

Among prosobranch gastropods, whether a species had planktotrophic or nonplanktotrophic development can be inferred through differences in the embryonic and larval shell morphology preserved at the apex of fossilized juveniles and adults (Thorson 1950, Shuto 1974, Jablonski \& Lutz 1983, Lima \& Lutz 1990). Both before and after the massive end-Cretaceous event, species with nonplanktotrophic development had approximately twice the extinction rate of species with planktotrophic development (Hansen 1978, Jablonski 1995). Such differential extinction has been attributed to differences in geographic ranges and population genetic structure owing to differences in dispersal ability (Shuto 1974, Hansen 1978, Jablonski \& Lutz 1983, Jablonski 1995), and so reflects true species selection in the restrictive sense (Grantham 1995). Note that fossil evidence can distinguish only between species with planktotrophic and nonplanktotrophic development, not between those with planktonic and aplanktonic development. Whereas all species with planktotrophic development have planktonic larvae, nonplanktotrophs can have either nonfeeding, dispersive larvae or aplanktonic development. However, at least some of the species with nonplanktotrophic development were likely to have been aplanktonic; if the greater susceptibility of nonplanktotrophic species to extinction is a consequence of limited dispersal ability, those nonplanktotrophic species with aplanktonic development should generally be affected to the greatest extent. Thus, species selection could have played an important role in creating or maintaining a high proportion of species with planktonic development, even if long-lived planktonic larvae are selectively disadvantageous on a short-term basis. Because of their lower extinction rates, species with planktotrophic development should accumulate over time.

But species with aplanktonic development seem to speciate at higher rates, in proportion to their smaller geographical ranges and lower dispersal potential (Hansen 1983, Jablonski \& Lutz 1983, Grantham 1995). This should promote a more rapid accumulation of species with aplanktonic development, not by conversion from one developmental pattern to the other, but through the more rapid proliferation of species with aplanktonic development. By this argument, the proportion of species with planktotrophic development should be diminishing with time. Thus, macroevolutionary forces could be acting during periods of background extinction either to increase or decrease the proportion of species with long-lived planktonic larvae, depending on the balance between extinction and speciation rates.

Among antarctic echinoids, species with phytoplanktotrophic larvae may have been especially vulnerable to decreased primary production during major glaciation events, perhaps accounting for the prevalence of brooding among present-day antarctic echi- 
noids (Poulin \& Féral 1996). Species with feeding larvae may also have been generally selected against during extinction events concluding both the Permian (Valentine 1986) and Ordovician (Chatterton \& Speyer 1989) periods (reviewed by Wray 1995), although it is not clear whether this would necessarily select for aplanktonic development or merely lecithotrophic development in general. For the more recent end-Cretaceous extinction, species with planktotrophic larvae were apparently neither more nor less vulnerable than species with nonplanktotrophic development, for both prosobranch gastropods (Jablonski 1986, 1995) and echinoids (Smith \& Jeffery 1998). Again, a greater vulnerability of species with aplanktonic development could not be determined through this type of analysis.

Let us consider a scenario in which species with aplanktonic development were more vulnerable during the end-Cretaceous extinction, and that species producing long-lived larvae were favored. If there was substantial selection for species with long-lived larvae, then the present preponderance of larvae in the lifehistories of benthic marine invertebrates may simply reflect insufficient time for species subsequently to lose larvae from the life cycle. We are just beginning to have estimates of how long it takes to evolve from one mode to another. The loss of the feeding pluteus from the life cycle of the echinoid Heliocidaris erythrogrammica probably required less than 10 million years (Wray \& Raff 1991) and the shift from planktonic to aplanktonic development for species within the asteroid family Asterinidae may have occurred within only 2 million years (Hart et al. 1997), in both cases only a small fraction of the time available since the last major extinction event. Even if species with planktonic development were favored during the end-Cretaceous extinction, lack of time to evolve alternate reproductive modes does not seem to explain the dominance of larvae in present-day life histories, particularly when species that lose larvae from the life cycle should then speciate at faster rates (Jablonski \& Lutz 1983, Grantham 1995).

In summary, extinction events, both major and minor, may have played a role in creating the presently observed distribution of planktonic development among benthic marine invertebrates, but the extent of that role is generally uncertain. Further resolution may be difficult to achieve unless there is some way to distinguish between fossilized nonplanktotrophs that developed as larvae and those that had aplanktonic development.

Role of developmental constraints. There may be developmental constraints limiting shifts in reproductive pattern; the events of embryogenesis may be so tightly orchestrated and mutually interdependent that even small perturbations can not be tolerated. Raff (1996) argues convincingly against such limitations for most of development, supporting suggestions advanced earlier by Garstang (1922) and de Beer (1958). The apparent modularity of key developmental steps, and the apparently common co-opting of duplicated genes (e.g. Shubin et al. 1997) for novel functions should make at least some radical shifts in developmental pathways easy to accomplish (Raff 1996). Development is subject to selection (Wray 1995, Byrne \& Cerra 1996, Raff 1996). Early, and especially later, in development the genetic modules apparently operate independently of each other, so that constraints on modification are largely removed (Raff 1996).

Role of physiological constraints. Brooding is often associated with small body size (reviewed by Strathmann \& Strathmann 1982, McHugh 1993, Giangrande 1997). In part, this association may reflect an inability of larger animals to adequately oxygenate larger broods (Strathmann \& Strathmann 1982). However, at least some larger individuals circumvent this potential constraint (reviewed by Grahame \& Branch 1985 , McHugh 1993). Moreover, selection for brooding among species with small-sized adults does not necessarily explain the production of larvae in species with larger adults: production of egg masses and egg capsules provides another means of keeping developmental stages out of the plankton (Pechenik 1979), and yet many large-bodied animals do not utilize such capsules or egg masses. Furthermore, many species that do encapsulate their offspring release larvae, not juveniles (Pechenik 1979, McHugh 1993).

Role of behavioral and anatomical constraints, and the problem of escape. Loss of larval stages may be difficult to accomplish if it requires substantial alteration of adult behavior or reproductive anatomy. Production of egg masses or egg capsules, or the development of specialized brood chambers among gastropods, for example, requires considerable anatomical specialization of adults (Fretter \& Graham 1994, Levin \& Bridges 1995). In addition, encapsulating embryos is feasible only if those embryos have evolved a means of escape from the capsules or jelly masses; larvae of at least some gastropod species escape from egg capsules by releasing a species-specific chemical (reviewed by Pechenik 1986a). Thus, whereas the transition between feeding and nonfeeding development may require only a small number of mutations (Wray 1995, Raff 1996), transition to aplanktonic development may require a considerably greater number of changes, for both adults and larvae; this could limit the opportunities for loss of larvae from life histories.

Two pieces of evidence argue against this. Firstly, aplanktonic development has been accomplished far more simply in some echinoderm species, without extensive morphological, physiological, and behavioral specialization by adults (McEdward \& Janies 1997; see 
Mooi \& David 1993 for some exceptions), and yet larval development still predominates. Secondly, the widespread appearance of mixed developments in invertebrate life histories (Pechenik 1979) also argues against anatomical specialization as an effective barrier to the evolution of aplanktonic development. Within mixed life histories, adults release free-swimming larvae from egg capsules, egg masses, or brood chambers: the machinery for switching to aplanktonic development - by increasing egg size, for example, or providing nurse eggs - is in place, and yet larvae persist. Surprisingly few cases of possible transitional stages from mixed development to aplanktonic development have been documented (Levin \& Bridges 1995). Unhealthy and disintegrating embryos of the gastropod Thais canaliculata (Spight 1977) and various species in the gastropod genus Crepidula (Hoagland 1986) are ingested by healthy capsulemates, suggesting a possible move toward aplanktonic development. Other examples may have been overlooked; alternatively, mixed life histories may be generally stable, selected for by reduced mortality in early development (Pechenik 1979, Grant 1983).

Role of population genetic structure. Even if larvae are generally disadvantageous in the short term, extensive gene flow may limit opportunities for shifts from planktonic to aplanktonic development. It may be difficult to lose larvae from life histories when local populations are largely or entirely renewed in each generation by large numbers of propagules derived from distant populations potentially experiencing different selective pressures; local reproductive success is in such cases effectively decoupled from recruitment success (Caley et al. 1996).

The extent of gene flow among populations has long been thought to play a central role in determining the rate of evolutionary change and the likelihood of speciation (Mayr 1970, Vermeij 1978, Slatkin 1985, Grant \& Silva-Tatley 1997). As with plants (e.g. Linhart \& Grant 1996), insects (e.g. Price 1984), amphibians (Storfer \& Sih 1998), and terrestrial mammals (Peacock \& Smith 1997), input from other populations reduces prospects for local genetic differentiation and speciation (Mayr 1970, Hartl 1980, Vermeij 1982, Valentine \& Jablonski 1983, Slatkin 1985. Futuyma 1986, Strathmann 1986. Yamada 1989, Barton 1992, Bossart \& Scriber 1995, Craddock et al. 1995, Scheltema 1995, Gallardo \& Carrasco 1996, García-Ramos \& Kirkpatrick 1997, Johannesson \& Tatarenkov 1997, King \& Lawson 1997, Kruuk \& Gilchrist 1997, Peacock \& Smith 1997). Even a low rate of input from distant populations can 'swamp selection' and prevent major evolutionary change (Mayr 1970. Barton 1992, Peterson 1996, Grant \& da Silva-Tatley 1997, King \& Lawson 1997). Consistent with this relationship, species with wide geographic ranges and planktonic larvae generally show less genetic variation among locations than do species with aplanktonic development (e.g. Janson 1987. Palumbi 1995, Gallardo \& Carrasco 1996, Williams \& Benzie 1996, Allcock et al. 1997, Hoskin 1997, De Wolf et al. 1998). Very small amounts of immigration can prevent differentiation due to genetic drift, and even when there is differential selection for or against certain alleles it is theoretically difficult to maintain alleles at low frequency (Slatkin 1985). Some studies document substantial genetic differentiation despite dispersive larvae in the life history (Koehn et al. 1980, Watts et al. 1990, Palumbi 1995, Edmands et al. 1996), but these results typically reflect differential postmetamorphic selection forces or the one-time recruitment of genetically distinct cohorts in different locations; the genetic differences are therefore not self sustaining or cumulative but must be renewed in each generation (Johnson \& Black 1984).

How can aplanktonic development evolve from planktonic precursors when genes for dispersal continually enter from outside-carried in by successfully dispersed larvae - and dilute local selective pressures that may favor reduced dispersal? What conditions facilitate loss of larval stages from life histories? Can the widespread existence of larvae in the life histories of marine invertebrates reflect, to some extent, the difficulty of losing larvae rather than selection for maintaining them?

Under what conditions might a population experiencing substantial gene exchange with other populations split off at least one genetically isolated population? Frequent shifts in ocean current systems during the Pleistocene epoch may account for greater speciation rates in the lobster genus Panulirus, by periodically reducing gene flow among populations (Pollock 1992). In addition, larvae may be retained in some areas by particular hydrographic conditions, which might also prevent input of larvae from outside populations (e.g. Hedgecock 1986, Parsons 1996); under such conditions aplanktonic development might arise under favorable selective pressures. It is probably not coincidental that aplanktonic development is especially well represented among certain island populations (Knudsen 1950, Moore 1977, Jablonski \& Lutz 1983) and other areas experiencing strong offshore currents. Although some island populations may have been founded by the arrival of long-distance larvae (reviewed by Jablonski \& Lutz 1983, Scheltema 1995), Johannesson (1988) has argued that successful colonization is more likely to be accomplished by the occasional arrival of aplanktonic individuals transported via rafted egg masses. Thus, a high incidence of aplanktonic development in a location could reflect either the evolutionary loss of larvae in situ under intense selection against dispersal (Jablonski \& Lutz 
1983), or an initial colonization of the area by aplanktonic developers, which then persisted and speciated. Studies of the phylogenetic history of island populations are needed to resolve this issue.

Aplanktonic development could also evolve from planktonic development despite extensive gene flow if certain life-history traits correlate with strongly heritable differences in tolerance to certain degrees of environmental stress. Suppose, for example, that larger eggs are associated both with shorter larval life and increased tolerance to low salinity in some particular species. Differential survival along a salinity gradient. (e.g. Koehn et al. 1980) would then select simultaneously for differences in physiological tolerance and differences in life-history pattern, through differences in egg size. Further up the estuary, where average salinities are lower, offspring would be less likely to be exported. Most importantly, those offspring remaining in the population would be less likely to mate with good dispersers in the next generation, because the best dispersers would be selected against by the low salinity before they reach reproductive maturity. This hypothetical mechanism provides a novel model for parapatric speciation. There is an obvious need for studies relating life-history characteristics to the variety of physical stresses experienced within the range of particular species, and studies documenting the heritability of differential tolerance to physiological stress. To date, Hilbish \& Koehn (1985) provide one of the few studies documenting the functional significance of genetic differentiation along a stress gradient.

\section{IMPLICATIONS OF HUMAN INFLUENCE AS A SELECTIVE AGENT ON INVERTEBRATE REPRODUCTIVE PATTERN}

In general, the species most likely to become extinct are those with small geographic ranges, limited dispersal potential, and limited tolerance of environmental stress, both biological and physical (Vermeij 1978. Carlton et al. 1991). To the extent that brooding and encapsulating species are associated with small ranges and limited dispersal, species with aplanktonic development should be least likely to persist in the face of global warming, increased UV penetration, and continued habitat degradation (e.g. Carlton et al. 1991, Byrne \& Cerra 1996). Although at least some brooding species have large geographical ranges (Johannesson 1988, Grant \& Silva-Tatley 1997) and show limited genetic differentiation over those ranges (Grant \& Silva-Tatley 1997), and although larval stages do not guarantee extensive dispersal (Palumbi 1995), the association between aplanktonic development and limited dispersal probably holds in general.
Extinction probabilities should also vary inversely with tolerance to environmental stress. To what extent does stress tolerance correlate with reproductive pattern? To the extent that greater physiological adaptability (plasticity) is a consequence of greater gene flow among populations (Yamada 1989, Parsons 1998), we might expect species producing well-dispersed larvae to be more tolerant of environmental stress. I do not believe that the relationship between adult susceptibility to stress and reproductive mode has ever formally been examined. But if larvae are generally more sensitive than earlier developmental stages to physical and chemical stress, and if brooding and encapsulation protect developing embryos from exposure to those stresses, then continued broad-scale pollutant input could select against larval stages, ultimately increasing the likelihood of extinctions from local calarnity.

To what extent are larvae more susceptible to pollutants and UV irradiation than species with aplanktonic development? We know that embryos and larvae are typically affected by pollutants at one-tenth to onehundredth the concentration required to affect juveniles and adults of the same species to the same degree in the same amount of time (reviewed by Pechenik 1987). The greater vulnerability of larvae compared with adults may be caused, at least in part, by faster accumulation of toxicants by larvae (Ringwood 1989). But to what extent do egg cases, gelatinous egg masses, and brood chambers prevent or reduce embryonic exposure to pollutants?

Surprisingly little is known about capsule, egg mass, or brood chamber permeability to water-soluble toxicants, or about the susceptibility of encapsulated or brooded embryos to pollutant stress (Pechenik 1986a). Middaugh \& Floyd (1978) suggested that extraembryonic membranes protect embryos of the crustacean Palaemonetes pugio from heavy-metal exposure, but they made no permeability measurements. The egg capsules of several prosobranch gastropods are permeable to glucose and other small organic molecules (Galtsoff et al. 1937, Carriker 1955, Pechenik 1982, 1983), and the gelatinous egg masses of the opisthobranch gastropod Melanochlamys diomedea (Woods \& DeSilets 1997), the polychaete Euypolymnia nebulosa (Bhaud \& Duchêne 1996), and several species in the gastropod genus Lacuna (Hertling 1928) are permeable to salts. These data imply that at least some encapsulating structures may allow heavy metals and other low molecular weight, water-soluble pollutants to reach developing embryos.

Few studies have specifically considered the degree to which encapsulating structures or brood chambers shield embryos from pollutant stress. Pechenik \& Miller (1983) found no reduction in hatching success when newly deposited egg capsules of the mud snail, Ilyan- 
assa obsoleta, were exposed to a high concentration of No. 2 fuel oil ( 1 ppm water-accommodated fraction) for 3 to $6 \mathrm{wk}_{\text {; }}$ embryos successfully hatched from about $90 \%$ of capsules (50 to 80 capsules per treatment) whether or not those capsules were incubated in the presence of fuel oil. Encapsulated embryos developed more slowly in the presence of the fuel oil, however, suggesting that the egg capsules may not have prevented fuel oil components from reaching the embryos. Instead, hatching success in the presence of oil may reflect insensitivity of nonfeeding embryonic stages to the fuel oil stress rather than impermeability of the capsule wall to oil compounds. Early-stage, nonfeeding embryos removed from capsules and exposed directly to 1 ppm No. 2 fuel oil were substantially more tolerant of the stress than were later-stage, feeding larvae (Pechenik \& Miller 1983). Ingestion of contaminated food is an important route of pollutant entry for a number of marine invertebrate species in both larval (Rossi \& Anderson 1976, Debroski \& Epifanio 1980, Reinfelder \& Fisher 1994) and adult stages (Boehm \& Quinn 1976 , Young 1977, Sanders et al. 1989, Weston 1990, Selck et al. 1998), but the relative importance of ingestion and diffusion in moving toxic substances into embryos and larvae needs to be studied in greater detail. Oil components may enter the intracapsular fluid but not affect embryos as long as they subsist on endogenous reserves. Exposing crab embryos (Cancer anthonyi) to sublethal concentrations of copper, cadmium, or mercury slowed development to hatching (Macdonald et al. 1988), again suggesting that the extraembryonic membranes were permeable to these heavy metals.

Alternatively, an oil coating on the outer surface of mud snail capsules may have reduced the rate of oxygen diffusion across the capsule wall and delayed development by that means; oxygen stress slows the development of moliuscan embryos (Morrison 1971 Chaffee \& Strathmann 1984, Cohen \& Strathmann 1996, Lee and Strathmann 1998). More data on the permeability of egg masses and egg cases to water-soluble pollutants are needed to understand the degree to which they confer protection. Brooded embryos of the freshwater cladoceran Daphnia magna are fully susceptible to both inorganic and organic toxicants (Baird et al. 1991); similar studies have not yet been conducted on marine species.

To evaluate the potentially protective benefits of encapsulated or brooded development with respect to pollution susceptibility, we must also know when in development biochemical defense mechanisms first become functional. If detoxification pathways become functional late in development, the potential benefits of encapsulation are greater, assuming that capsules effectively shield embryos from those stresses. However, the limited data gathered to date indicate that detoxifi- cation pathways can become active very early in development. Certain metal-binding proteins, for example, are already present in early embryos of the sea urchin Strongylocentrotus intermedius (Scudiero et al. 1996). Similarly, Toomey and Epel (1993) have demonstrated a multixenobiotic transport protein that is already functional in embryos of the echiuran worm Urechis caupo and may be responsible for their substantial tolerance to environmental toxins. Larvae of the crab Cancer anthonyi survived exposure to copper and zinc if embryos were exposed to low concentrations of these elements earlier in development, implying induction of metalbinding proteins (Macdonald et al. 1988). I know of no comparable data for other marine invertebrates, particularly those which begin their lives within encapsulating structures or brood chambers. A cytochrome $\mathrm{p}_{450}$ monooxygenase system that oxidizes toxic organic compounds has been described from adults in a number of marine invertebrate groups (e.g. Fries \& Lee 1984, den Beston et al. 1990) and from larval fishes (e.g. Peters \& Livingstone 1996), but when the system becomes functional during the development of marine invertebrates has not yet been documented.

Laboratory studies have documented for a number of species that larvae are vulnerable to UV irradiation (reviewed by Gleason \& Wellington 1995, Morgan 1995a, Rawlings 1996). And Rawlings (1996) has demonstrated that egg capsules produced by the gastropod Nucella emarginata are highly effective at absorbing UV-B irradiation, and somewhat effective in protecting embryos from UV-A irradiation. These limited data suggest that encapsulation may protect embryos from UV exposure. But, as discussed earlier, the results of laboratory studies can be misleading in that in nature larvae may readily avoid exposure to environmental stresses; even though egg capsules of at least some species confer a degree of protection from UV irradiation and perhaps pollution stress as well, capsules may also increase exposure to these stresses by confining embryos to stressful habitats from which larvae are readily dispersed.

To evaluate the relative susceptibility of larval stages to pollution and UV irradiation, we need more information concerning (1) the relative roles of diffusion. and ingestion in the uptake of pollutants by developing embryos and larvae; (2) the stage in development at which detoxification systems first become functional; (3) the permeability properties of encapsulating structures and brood chambers; and (4) the relative magnitude and duration of exposure to these stresses for free-living larvae and encapsulated embryos.

To the extent that encapsulated and brooded embryos are fully exposed to environmental stresses, continued habitat degradation should favor dispersal as a means of escape from local conditions, and thus select 
for retention of larvae in life histories. On the other hand, extensive habitat degradation and corresponding local extinctions could facilitate the loss of larvae from life histories by potentially isolating subpopulations from the homogenizing effects of dispersal. Understanding the direction of evolutionary change favored by human influence requires more data on the relative tolerances and susceptibilities of embryos and larvae of closely related species, and more data on the permeability properties of capsules, egg masses, and brood chambers. We also need a better understanding of the conditions under which extensive gene flow can maintain larvae in life histories despite selective pressures favoring their loss.

\section{SUMMARY}

Planktonic larval stages are common components of the life cycles of benthic marine invertebrates, even though the evolutionary trend seems biased toward their loss. There are both advantages and disadvantages associated with having larval stages in the life cycle (Table 2). The apparent reacquisition of larval stages within a few clades suggests that larvae can, under at least some circumstances, be selected for. However, the widespread distribution of larvae is not readily explained from energetic considerations, and the major advantage, dispersal, may be only a consequence of having larvae, not a selective agent maintaining them in the life cycle. The apparently biased transitions from planktonic to aplanktonic development within many groups (including prosobranch gastropods, polychaetes, ascidians, and echinoderms) suggest, in fact, that larvae are, on balance, a liability. Selective pressures operating to remove larvae from life cycles are probably not large, as long as adults can produce enough larvae to overcome the losses associated with dispersal away from favorable sites, predation in the plankton, and predation during substrate searching. It seems equally likely that larvae are not easily lost from life histories in which local populations are largely or entirely renewed by large numbers of individuals derived from other populations. The present distribution of planktonic and aplanktonic development may also be shaped, at least in part, by long-term macroevolutionary forces reflecting the differences in geographic ranges and population genetic structure associated with differences in dispersal potential between the two major modes of development: planktonic species tend to have lower extinction rates while species with aplanktonic development tend to speciate with greater frequency.

To better understand the forces that have shaped the present distribution of planktonic and aplanktonic
Table 2. Summary of advantages and disadvantages associated with having larvae in the benthic marine invertebrate life cycle

\section{Advantages}

Greater dispersal potential:

a. reduced competition for food among siblings (planktotrophs only)

b. reduced competition between parent and offspring

c. increased ease of recolonization following local extinction

d. reduced likelihood of inbreeding

e. large geographic range

f. lower risk of extinction, greater persistence in geological time

Metamorphosis triggered by specific cues:increased probability that juveniles will occupy favorable habitat

Lower total energetic expense of reproduction(?)

\section{Disadvantages}

Dispersal away from favorable parental habitat Increased vulnerability to planktonic predators Increased vulnerability to benthic predators(?)

Greater vulnerability to chemical and UV stress(?)

Greater gene flow over greater distances:

a. reduced opportunity for local adaptation

b. increased likelihood of outbreeding depression Substrate specificity for metamorphosis:

a. larvae might metamorphose under suboptimal or disadvantageous conditions

b. might limit ability of adults to shift or expand niche Reduced juvenile fitness through delayed metamorphosis Nutritional and other stresses experienced by larvae can reduce postmetamorphic performance

Greater total energetic expense of reproduction(?)

development, and to better understand how human activities might alter or accelerate selective regimes in the future, more information on the following points is needed:

(1) the relative vulnerability of larvae and encapsulated embryos to both planktonic and benthic predation, and the extent to which vulnerability to predators increases or decreases with increasing larval size;

(2) the relative vulnerability of larvae and encapsulated embryos to physical and chemical stress, and the degree to which larvae and encapsulated stages are exposed to such stresses in the field;

(3) the extent to which larval and encapsulated experiences affect postmetamorphic fitness;

(4) the frequency with which larvae have been regained within clades once lost, and the amount of time and genetic change required to evolve from one mode to the other in different groups;

(5) the relative importance of ingestion and diffusion in the uptake of pollutants by larvae, and the extent to which encapsulating structures and brood chambers prevent such uptake 
(6) when in development biochemical detoxification systems first become functional;

(7) the extent to which substrate specificity for metamorphosis increases juvenile survival in the field, and the extent to which it limits the opportunities for expanding adult niches or places juveniles into suboptimal habitats; and

(8) the extent to which the population genetic consequences of dispersal can deter the loss of larvae from life cycles in the face of selection for their loss, and the conditions under which subpopulations of species with planktonic development may become isolated from other populations.

The prevalence of dispersive larvae in the life histories of benthic marine invertebrates may, to a large extent, reflect the difficulty of losing larvae from the life cycle more than selection for their maintenance in the life cycle. It will be important to determine whether the conditions under which larvae can be lost from life cycles are limited, and if so, what those limitations are.

Acknowledgements. This paper is based on a keynote address delivered at the Aquatic Life Cycle Strategies conference in Plymouth, England in April 1997. I am grateful to Dr. Michael Whitfield for inviting me to the conference, and for suggesting that I think about larvae as a possible Achilles' heel in invertebrate life cycles. The manuscript has benefited from the questions and suggestions of conference participants; my colleagues G. Hendler, D. Jablonski, L. McEdward, D. McHugh, D. Morritt, C. Orians, M. Reed, and D. Wendt; and 2 anonymous reviewers. I am grateful to all for their advice, encouragement, and stimulating discussion.

\section{LITERATURE CITED}

Allcock AL, Brierley AS, Thorpe JP, Rodhouse PG (1997) Restricted gene flow and evolutionary divergence between geographically separated populations of the Antarctic octopus Pareledone turqueti. Mar Biol 129:97-102

Anderson DT (1994) Barnacles: structure, function, development and evolution. Chapman \& Hall, New York

André C, Jonsson PR, Lindegarth M (1993) Predation on settling bivalve larvae by benthic suspension feeders: the role of hydrodynamics and larval behaviour. Mar Ecol Prog Ser 97:183-192

Anger K (1996) Salinity tolerance of the larvae and first juveniles of a semiterrestrial grapsid crab, Armases miersii (Rathbun). J Exp Mar Biol Ecol 202:205-223

Arndt A, Marquez C, Lambert P, Smith MJ (1996) Molecular phylogeny of eastern Pacific sea cucumbers (Echinodermata: Holothuroidea) based on mitochondrial DNA sequence. Mol Phylogenetics Evol 6:425-437

Ayers JC (1956) Population dynamics of the marine clam, Mya arenaria. Limnol Oceanogr 1:26-36

Bailey KM, Batty RS (1983) A laboratory study of predation by Aurelia aurita on larval herring (Clupea harengus): experimental observations compared with model predictions. Mar Biol 72:295-301

Bailey KM, Houde ED (1989) Predation on eggs and larvae of marine fishes and the recruitment problem. Adv Mar Biol $25: 1-83$
Baird DJ, Barber I, Soares AMVM, Calow P (1991) An early life-stage test with Daphnia magna Straus: an alternative to the 21-day chronic test? Ecotox Environ Safe 22:1-7

Bambang Y, Charmantier G, Thuet P, Trilles JP (1995) Effect of cadmium on survival and osmoregulation of various developmental stages of the shrimp Panaeus japonicus (Crustacea: Decapoda). Mar Biol 123:443-450

Barton NH (1992) On the spread of new gene combinations in the third phase of Wright's shifting-balance. Evolution 46 : $551-557$

Bernays EA, Chapman RG (1978) Plant chemistry and acridoid feeding behavior. In: Harborne JB (ed) Coevolution of plants and animals. Academic Press, New York, p 100-141

Berrill NJ (1931) Studies in tunicate development. Part II. Abbreviation of development in the Molgulidae. Phil Trans R Soc B 219:281-346

Bertness MD (1989) Intraspecific competition and facilitation in a northern acorn barnacle population. Ecology 70: $257-268$

Bhaud M, Duchêne JC (1996) Change from planktonic to benthic development: is life cycle evolution an adaptive answer to the constraints of dispersal? Oceanol Acta 19:335-346

Bickell LR, Kempf SC (1983) Larval and metamorphic morphogenesis in the nudibranch Melibe leonina (Mollusca: Opisthobranchia). Biol Bull 165:119-138

Biermann CH, Schinner GO, Strathmann RR (1992) Influence of solar radiation, microalgal fouling, and current on deposition site and survival of embryos of a dorid nudibranch gastropod. Mar Ecol Prog Ser 86:205-215

Bigford TE (1977) Effects of oil on behavioral responses to light, pressure and gravity in larvae of the rock crab Cancer irroratus. Mar Biol 43:137-148

Boehm PD, Quinn JG (1976) The effect of dissolved organic matter in sea water on the uptake of mixed individual hydrocarbons and number 2 fuel oil by a marine filterfeeding bivalve (Mercenaria mercenaria). Estuar Coast Mar Sci 4: $93-105$

Boettcher AA, Targett NM (1996) Induction of metamorphosis in queen conch, Strombus gigas Linnaeus, larvae by cues associated with red algae from their nursery grounds. J Exp Mar Biol Ecol 196:29-52

Bossart L, Scriber JM (1995) Maintenance of ecologically significant genetic variation in the tiger swallowtail butterfly through differential selection and gene flow. Evolution 49: $1163-1171$

Brenchley GA (1982) Predation on encapsulated larvae by adults: effects of introduced species on the gastropod Ilyanassa obsoleta. Mar Ecol Prog Ser 9:255-262

Brown JH, Kodric-Brown A (1977) Turnover rates in insular biogeography: effect of immigration on extinction. Ecology 58:445-449

Bryan GW, Gibbs PE, Burt GR (1.988) A comparison of the effectiveness of tri- $n$-butyltin chloride and five other organotin compounds in promoting the development of imposex in the dog-whelk, Nucella lapillus. J Mar. Biol Assoc UK 68:733-744

Bryan PJ, Qian PY, Kreider JL, Chia FS (1997) Induction of larval settlement and metamorphosis by pharmacological and conspecific associated compounds in the serpulid polychaete Hydroides elegans. Mar Ecol Prog Ser 146: $81-90$

Burke RD (1983) The induction of metamorphosis of marine invertebrate larvae: stimulus and response. Can J Zool 61: $1701-1719$

Burton RS (1986) Evolutionary consequences of restricted gene flow among natural populations of the copepod, Tigriopus californicus. Bull Mar Sci 39:526-535 
Byrne M (1996) Viviparity and intragonadal cannibalism in the diminutive sea stars Patiriella vivipara and P. parvivipara (family Asterinidae). Mar Biol 125:551-567

Byrne M, Barker MF (1991) Embryogenesis and larval development of the asteroid Patiriella regularis viewed by light and scanning electron microscopy. Biol Bull 180:332-345

Byrne M, Cerra A (1996) Evolution of intragonadal development in the diminutive asterinid sea stars Patiriella vivipara and $P$. parvivipara with an overview of development in the Asterinidae. Biol Bull 191:17-26

Calabrese A, Rhodes EW (1974) Culture of Mulinia lateralis and Crepidula fornicata embryos and larvae for studies of pollution effects. Thalassia Jugosl 10:89-102

Caley MJ, Carr MH, Hixon MA, Hughes TP, Jones GP, Menge BA (1996) Recruitment and the local dynamics of open marine populations. Annu Rev Ecol Syst 27:477-500

Carlton JT, Vermeij GJ, Lindberg DR, Carlton DA, Dudley EC (1991) The first historical extinction of a marine invertebrate in an ocean basin: the demise of the eelgrass limpet Lottia alveus. Biol Bull 180:72-80

Carriker MR (1951) Ecological observations on the distribution of oyster larvae in New Jersey estuaries. Ecol Monogr 21:19-38

Carriker MR (1955) Critical review of biology and control of oyster drills, Urosalpinx cinerea and Eupleura caudata. Spec Sci Rep US Fish Wildl Serv 148: 225-254

Chaffee C, Lindberg DR (1986) Larval biology of early Cambrian molluscs: the implications of small body size. Bull Mar Sci 39:536-549

Chaffee C, Strathmann RR (1984) Constraints on egg masses. I. Retarded development within thick egg masses. J Exp Mar Biol Ecol 84:73-83

Chaparro OR, Oyarzun RF, Vergara AM, Thompson RJ (1999) Energy investment in nurse eggs and egg capsules in Crepidula dilatata Lamarck (Gastropoda, Calyptraeidae) and its influence on the hatching size of the juvenile. J Exp Mar Biol Ecol 232:261-214

Chaparro OR, Paschke KA (1990) Nurse egg feeding and energy balance in the embryos of Crepidula dilitata (Gastropoda: Calyptraeidae) during intracapsular development. Mar Ecol Prog Ser 65:183-191

Chatterton BDE, Speyer SE (1989) Larval ecology, life history strategy, and patterns of extinction and survivorship among Ordovician trilobites. Paleobiology 15:118-132

Chia FS (1974) Classification and adaptive significance of developmental patterns in marine invertebrates. Thalassia Jugosl 10:121-130

Chia FS, Buckland-Nicks J, Young CM (1984) Locomotion of marine invertebrate larvae: a review. Can J Zool 62 : $1205-1222$

Chia FS, Gibson GD, Qian PY (1996) Poecilogony as a reproductive strategy of marine invertebrates. Oceanol Acta 19: 203-208

Cohen CS, Strathmann RR (1996) Embryos at the edge of tolerance: effects of environment and structure of egg masses on supply of oxygen to embryos. Biol Bull 190:8-15

Coon SL, Walch M, Fitt WK, Weiner RM, Bonar DB (1990) Ammonia induces settlement behavior in oyster larvae. Biol Bull 179:297-303

Costlow JD Jr, Bookhout CG, Monroe R (1960) The effect of salinity and temperature on larval development of Sesarma cinereum (Bosc) reared in the laboratory. Biol Bull 118:183-202

Costlow JD Jr, Bookhout CG, Monroe R (1966) Studies on the larval development of the crab, Rhithropanopeus harrisii (Gould). I. The effect of salinity and temperature on larval development. Physiol Zool 39:81-100
Cowan JH Jr, Houde ED (1992) Size-dependent predation on marine fish larvae by ctenophores, scyphomedusae, and planktivorous fish. Fish Oceanogr 1:113-126

Cowan JH Jr, Houde ED (1993) Relative predation potentials of scyphomedusae, ctenophores and planktivorous fish on ichthyoplankton in Chesapeake Bay. Mar Ecol Prog Ser 95:55-65

Cowan JH Jr, Houde ED, Rose KA (1996) Size-dependent vulnerability of marine fish larvae to predation: an individualbased numerical experiment. ICES J Mar Sci 53:23-37

Cowen RK, Sponaugle S (1997) Relationships between early life history traits and recruitment among coral reef fishes. In: Chambers RC, Trippel EA (eds) Early life history and recruitment in fish populations. Chapman \& Hall, London, p $423-449$

Craddock C, Hoeh WR, Lutz RA, Vrijenhoek RC (1995) Extensive gene flow among mytilid (Bathymodiolus thermophilus) populations from hydrothermal vents of the eastern Pacific. Mar Biol 124:137-146

Crisp DJ (1974) Factors influencing the settlement of marine invertebrate larvae. In: Grant PT, Mackie AM (eds) Chemoreception in marine organisms. Academic Press, NewYork, p $177-265$

Cronin TW, Forward RB Jr (1986) Vertical migration cycles of crab larvae and their role in larval dispersal. Bull Mar Sci 39:192-201

Crowder LB, Squires DD, Rice JA (1997) Nonadditive effects of terrestrial and aquatic predators on juvenile estuarine fish. Ecology 78:1796-1804

Davis AR, Butler AJ (1989) Direct observations of larval dispersal in the colonial ascidian Podoclavella moluccensis Sluiter: evidence for closed populations. J Exp Mar Biol Ecol 127:189-203

de Beer G (1958) Embryos and ancestors, 3rd edn. Oxford University Press, Oxford

den Besten PJ, Herwig HJ, van Donselaar EG, Livingstone DR (1990) Cytochrome P-450 monooxygenase system and benzo(a)pyrene metabolism in echinoderms. Mar Biol 107: $171-177$

Debroski CJ Jr, Epifanio CE (1980) Accumulation of a benzo[a]-pyrene in a larval bivalve via trophic transfer. Can J Fish Aquat Sci 37: 2318-2322

De Wolf H, Backeljau T, Verhagen R (1998) Spatio-temporal genetic structure and gene flow between two distinct shell morphs of the planktonic developing periwinkle Littorina striata (Mollusca: Prosobranchia). Mar Ecol Prog Ser 163: $155-163$

Dirnberger JM (1993) Dispersal of larvae with a short planktonic phase in the polychaete Spirorbis spirillum (Linnaeus). Bull Mar Sci 52:898-910

Doyle R (1975) Settlement of planktonic larvae: a theory of habitat selection in varying environments. Am Nat 109: $113-126$

Economou AN (1991) Is dispersal of fish eggs, embryos and larvae an insurance against density dependence? Environ Biol Fish 31:313-321

Edmands S, Moberg PE, Burton RS (1996) Allozyme and mitochondrial DNA evidence of population subdivision in the purple sea urchin Strongylocentrotus purpuratus. Mar Biol 126:443-450

Elliott JK, Leggett WC (1996) The effect of temperature on predation rates of a fish (Gasterosteus aculeatus) and a jellyfish (Aurelia aurita) on larval capelin (Mallotus villosus). Can J Fish Aquat Sci 53:1393-1402

Emlet RB, Hoegh-Guldberg O (1997) Effects of egg size on postlarval performance: experimental evidence from a sea urchir. Evolution 51:141-152 
Emlet RB, McEdward LR, Strathmann RR (1987) Echinoderm larval ecology viewed from the egg. In: Jangoux $M$, Lawrence JM (eds) Echinoderm studies. Vol 2. Balkema. Rotterdam, p 55-136

Engstrom NA (1982) Brooding behavior and reproductive biology of a subtidal Puget Sound sea cucumber Cucumaria lubrica (Clark, 1901) (Echinodermata: Holothuroidea). In: Lawrence JM (ed) Echinoderms: proceedings of the international conference, Tampa Bay. Balkema, Rotterdam, p 447-450

Eyster LS (1986) The embryonic capsules of nudibranch molluscs: literature review and new studies on albumen and capsule wall ultrastructure. Am Malac Bull 4:205-216

Fenaux L, Strathmann MF, Strathmann RR (1994) Five tests of food-limited growth of larvae in coastal waters by comparisons of rates of development and form of echinoplutei Limnol Oceanogr 39:84-98

Fitzgerald TP, Forward RB Jr, Tankersley RA (1998) Metamorphosis of the estuarine crab Rithropanopeus harrisii: effect of water type and adult odor. Mar Ecol Prog Ser 165 $217-223$

Fortier L, Villeneuve A (1996) Cannibalism and predation on fish larvae by larvae of Atlantic mackerel, Scomber scombrus: trophodynamics and potential impact on recruitment. Fish Bull US 94:268-281

Forward RB Jr (1985) Behavioral responses of larvae of the crab Rhithropanopeus harrisii (Brachyura: Xanthidae) during diel vertical migration. Mar Biol 90:9-18

Forward RB Jr, Hettler WF Jr (1992) Effects of feeding and predator exposure on photoresponses during diel vertical migration of brine shrimp larvae. Limnol Oceangr 37: $1261-1270$

Forward RB Jr, Lohmann K, Cronin TW (1982) Rhythms in larval release by an estuarine crab (Rhithropanopeus harrisii). Biol Bull 163:287-300

Fox CW, LaLonde RG (1993) Host confusion and the evolution of insect diet breadths. Oikos 67:577-581

Fretter V, Graham A (1994) British prosobranch molluscs: their functional anatomy and ecology. The Ray Society, London, $\mathrm{p} 416-443$

Fries CR, Lee RF (1984) Pollutant effects of the mixed function oxygenase (MFO) and reproductive systems of the marine polychaete Nereis virens. Mar Biol 79:187-193

Fuiman LA (1989) VuInerability of Atlantic herring larvae to predation by yearling herring. Mar Ecol Prog Ser 51 $291-299$

Fuiman LA (1994) The interplay of ontogeny and scaling in the interactions of fish larvae and their predators. J Fish Biol 45 (Suppl A):55-79

Futuyma DJ (1998) Evolutionary biology, 3nd edn. Sinauer Associates Inc, Sunderland, MA, p 482-503

Gaines SD, Lafferty KD (1995) Modeling the dynamics of marine species: the importance of incorporating larval dispersal. In: McEdward L (ed) Ecology of marine invertebrate larvae. CRC Press, Boca Raton, FL, p 389-412

Gallardo CS (1977) Two modes of development in the morphospecies Crepidula dilitata (Gastropoda: Calyptraeidae) from southern Chile. Mar Biol 39:241-251

Gallardo CS (1979) Developmental pattern and adaptations for reproduction in Nucella crassilabrum and other muri. cacean gastropods. Biol Bull 157:453-463

Gallardo CS, Perron FE (1982) Evolutionary ecology of reproduction in marine benthic molluscs. Malacologria 22:109-114

Gallardo $\mathrm{MH}_{1}$ Carrasco JI (1996) Genetic cohesiveness among populations of Concholepas concholepas (Gastropoda, Muricidae) in southern Chile. J Exp Mar Biol Ecol $197: 237-249$
Galtsoff PS, Prytherch HF, Engle JB (1937) Natural history and methods of controlling the common oyster drills Urosalpinx cinerea Say and Eupleura caudata (Say). US Bur Fish Wildl Serv Circ 25:1-24

García-Ramos G, Kirkpatrick M (1997) Genetic models of adaptation and gene flow in peripheral populations. Evolution 51:21-28

Garstang W (1922) The theory of recapitulation: a critical restatement of the biogenetic law. J Linn Soc (Zool) 35: $81-101$

Gebauer P, Walter I, Anger K (1998) Effects of substratum and conspecific adults on the metamorphosis of Chasmagnathus granulata (Dana) (Decapoda: Grapsidae) megalopae. J Exp Mar Biol Ecol 223:185-198

Gebruk AV, Tyler PA, Billett DSM (1997) Pelagic juveniles of the deep-sea elasipodid holothurians: new records and review. Ophelia 46:153-164

Giangrande A (1997) Polychaete reproductive patterns, lifecycles and life-histories: an overview. Oceanogr Mar Biol Annu Rev 35:323-386

Giangrande A, Geraci S, Belmonte G (1994) Life-cycle and life-history diversity in marine invertebrates and the implications in community dynamics. Oceanogr Mar Biol Annu Rev 32:305-333

Gibbs PE (1968) Observations on the population of Scoloplos armiger at Whitsable. J Mar Biol Assoc UK 48:225-254

Gibson G (1995) Why be choosy? Temporal changes in larval sensitivity to several naturally-occurring metamorphic inducers in the opisthobranch Haminaea callidegenita. J Exp Mar Biol Ecol 194:9-24

Giese AC, Pearse JS (1974) Reproduction of marine invertebrates. Vol I. Introduction: general principles. Academic Press, New York

Gili C, Martinell J (1994) Relationship between species longevity and larval ecology in nassariid gastropods. Lethaia 27:291-299

Gleason DF, Wellington GM (1995) Variation in UVB sensitivity of planula larvae of the coral Agaricia agaricites along a depth gradient. Mar Biol 123:693-703

Gleason TR, Bengtson DA (1996) Growth, survival and sizeselective predation mortality of larval and juvenile inland silversides, Menidia beryllina (Pisces; Atherinidae). J Exp Mar Biol Ecol 199:165-177

Gosselin LA, Chia FS (1995) Characterizing temperate rocky shores from the perspective of an early juvenile snail: the main threats to survival of newly hatched Nucella emarginata. Mar Biol 122:625-635

Gosselin LA, Qian PY (1996) Early post-settlement mortality of an intertidal barnacle: a critical period for survival. Mar Ecol Prog Ser 135:69-75

Gosselin LA, Qian PY (1997) Juvenile mortality in benthic marine invertebrates. Mar Ecol Prog Ser 146:265-282

Grahame J (1977) Reproductive effort and r- and K-selection in two species of Lacuna (Gastropoda: Prosobranchia). Mar Biol 40:217-224

Grahame J (1982) Energy flow and breeding in two species of Lacuna: comparative costs of egg production and maintenance. Int J Invertebr Reprod Dev 5:91-99

Grahame J, Branch GM (1985) Reproductive patterns of marine invertebrates. Oceanogr Mar Biol Annu Rev 23: 373-398

Grant A (1983) On the evolution of brood protection in marine benthic invertebrates. Am Nat 122:549-555

Grant WS, Silva-Tatley da FM (1997) Lack of genetically-subdivided population structure in Bullia digitalis, a southern African marine gastropod with lecithotrophic development. Mar Biol 129:123-137 
Grantham TA (1995) Hierarchical approaches to macroevolution: recent work on species selection and the effect hypothesis' Annu Rev Ecol Syst 26:301-321

Hadfield MG (1986) Settlement and recruitment of marine invertebrates: a perspective and some proposals. Bull Mar Sci 39:418-425

Hadfield MG, laea DK (1989) Velum of encapsulated veligers of Petaloconchus (Gastropoda), and the problem of re-evolution of planktotrophic larvae. Bull Mar Sci 45:377-386

Hadfield MG, Schever D (1985) Evidence for a soluble metamorphic inducer in Phestilla: ecological, chemical and biological data. Bull Mar Sci 37:556-566

Hadfield MG, Strathmann MF, Strathmann RR (1997) Ciliary currents of non-feeding veligers in putative basal clades of gastropods. Invertebr Biol 116:313-321

Hansen TA (1978) Larval dispersal and species longevity in Lower Tertiary gastropods. Science 199:885-887

Hansen TA (1983) Modes of larval development and rates of speciation in early Tertiary neogastropods. Science 220: $501-502$

Harms J (1992) Larval development and delayed metamorphosis in the hermit crab Clibanarius erythropus (Latreille) (Crustacea, Diogenidae). J Exp Mar Biol Ecol 156:151-160

Hart MW, Byrne M, Smith MJ (1997) Molecular phylogenetic analysis of life-history evolution in asterinid starfish. Evolution 51:1848-1861

Hartl DL (1980) Principles of population genetics. Sinauer Associates, Inc, Sunderland, MA, p 189-197

Harvell CD, West M, Griggs C (1996) Chemical defense of embryos and larvae of a West Indian gorgonian coral, $\mathrm{Bri}$ areum asbestinum. Invertebr Reprod Dev 30:1-3

Harvey AW (1996) Delayed metamorphosis in Florida hermit crabs: multiple cues and constraints (Crustacea: Decapoda: Paguridae and Diogenidae). Mar Ecol Prog Ser $141: 27-36$

Harvey AW, Colasurdo EA (1993) Effects of siell and food availability on metamorphosis in the hermit crabs Pagurus hirsutiusculus (Dana) and Pagurus granosimanus (Stimpson). J Exp Mar Biol Ecol 165:237-249

Havenhand JN (1995) Evolutionary ecology of larval types. In: McEdward L (ed) Ecology of marine invertebrate larvae. CRC Press, Boca Raton, FL, p 79-122

Heath MR (1992) Field investigations of the early life stages of marine fish. Adv Mar Biol 28:1-174

Hedgecock D (1986) Is gene flow from pelagic larval dispersal important in the adaptation and evolution of marine invertebrates? Bull Mar Sci 39:550-564

Helmuth B, Veit RR, Holberton R (1994) Long-distance dispersal of a sub-Antarctic brooding bivalve (Gaimardia trapesina) by kelp-rafting. Mar Biol 120:421-426

Hendle G (1975) Adaptational significance of the patterns of ophiuroid development. Am Zool 15:691-715

Hendler G (1991) Echinodermata: Ophiuroidea. In: Giese AC, Pearse JS, Pearse VB (eds) Reproduction of marine invertebrates. Vol VI. Boxwood Press, Pacific Grove, CA, p 355-511

Hendler G, Franz DR (1971) Population dynamics and life history of Crepidula convexa Say (Gastropoda: Prosobranchia) in Delaware Bay. Biol Bull 141:514-526

Hendler G, Franz DR (1982) The biology of a brooding seastar, Leptasterias tenera, in Block Island Sound. Biol Bull 162:273-289

Hertling $H$ (1928) Beobachtungen und Versuche an den Eiern von Littorina und Lacuna. Bedeutung der Eihüllen. Entwicklung im natürlichen und abgeänderten Medium. Wiss Meeresunters (Abt Helgoland) 17:1-49
Heslinga GA (1976) Effects of copper on the coral-reef echinoid Echinometra mathaei. Mar Biol 35:155-160

Hidu H (1969) Gregarious setting in the American oyster Crassostrea virginica Gmelin. Chesapeake Sci 10:85-92

Highsmith RC (1982) Induced settlement and metamorphosis of sand dollar (Dendraster excentricus) larvae in predatorfree sites: adult sand dollar beds. Ecology 63:329-337

Highsmith RC (1985) Floating and algal rafting as potential dispersal mechanisms in brooding invertebrates. Mar Ecol Prog Ser 25:169-179

Highsmith RC, Emlet RB (1986) Delayed metamorphosis effect on growth and survival of juvenile sand dollars (Echinoidea: Clypeasteroida). Bull Mar Sci 39:347-361

Hilbish TJ, Koehn RK (1985) Exclusion of the role of secondary contact in an allele frequency cline in the mussel Mytilus edulis. Evolution 39:432-443

Hill AE (1991) Advection-diffusion-mortality solutions for investigating pelagic larval dispersal. Mar Ecol Prog Ser $70: 117-128$

Hines AH (1986) Larval problems and perspectives in life histories of marine invertebrates. Bull Mar Sci 39:506-525

Hoagland KE (1986) Patterns of encapsulation and brooding in the Calyptraeidae (Prosobranchia: Mesogastropoda) Am Malac Bull 4:173-183

Holland DL, Crisp DJ, Huxley R, Sisson J (1984) Influence of oil shale on intertidal organisms: effect of oil shale extract on settlement of the barnacle Balanus balanoides (L.) J Exp Mar Biol Ecol 75:245-255

Holt R, McPeek MA (1996) Chaotic population dynamics favors the evolution of dispersal. Am Nat 148:709-718

Hoskin MG (1997) Effects of contrasting modes of larval development on the genetic structures of populations of three species of prosobranch gastropods. Mar Biol 127:647-656

Hunt HL, Scheibling RE (1997) Role of early post-settlement mortality in recruitment of benthic marine invertebrates. Mar Ecol Prog Ser 155:269-301

Husband BC, Schemske DW (1997) The effect of inbreeding in diploid and tetraploid populations of Epilobium angustifolium (Onagraceae): implications for the genetic basis of inbreeding depression. Evolution 51:737-746

Istock CA (1967) The evolution of complex life cycle phenomena; an ecological perspective. Evolution 21:592-605

Jablonski D (1986) Larval ecology and macroevolution in marine invertebrates. Bull Mar Sci 39:565-587

Jablonski D (1995) Extinctions in the fossil record. In: Lawton JH, May RM (eds) Extinction rates. Oxford University Press, Oxford, p 25-44

Jablonski D, Lutz RA (1983) Larval ecology of marine benthic invertebrates: paleobiological implications. Biol Rev 58: $21-89$

Jackson GA, Strathmann RR (1981) Larval mortality from offshore mixing as a link between precompetent and competent periods of development. Am Nat 118:16-26

Jackson JBC (1986) Modes of dispersal of clonal benthic invertebrates: consequences for species' distributions and genetic structure of local populations. Bull Mar Sci 39:588-606

Jägersten G (1972) Evolution of the metazoan life cycle. Academic Press, New York

Janson K (1987) Allozyme and shell variation in two marine snails (Littorina, Prosobranchia) with different dispersal abilities. Biol J Linn Soc 30: 245-256

Jarrett JN (1997) Temporal variation in substrate specificity of Semibalanus balanoides (Linnaeus) cyprids. J Exp Mar Biol Ecol 211:103-114

Jarrett JN, Pechenik JA (1997) Temporal variation in cyprid quality and juvenile growth capacity for an intertidal barnacle. Ecology 78:1262-1265 
Jeffery WR (1997) Evolution of ascidian development. BioScience 47:417-425

Jensen RA, Morse DE (1984) Intraspecific facilitation of larval recruitment: gregarious settlement of the polychaete Phragmatopoma californica (Fewkes). J Exp Mar Biol Ecol $83: 107-126$

Johannesson K (1988) The paradox of Rockall: why is a brooding gastropod (Littorina saxatilis) more widespread than one having a planktonic larval dispersal stage (L. littorea)? Mar Biol 99:507-513

Johannesson K, Tatarenkov A (1997) Allozyme variation in a snail (Littorina saxatilis)-deconfounding the effects of microhabitat and gene flow. Evolution 51:402-409

Johnson KB, Brink LA (1998) Predation on bivalve veligers by polychaete larvae. Biol Bull 194:297-303

Johnson MS, Black R (1984) Pattern beneath the chaos: the effect of recruitment on genetic patchiness in an intertidal limpet. Evolution 38:1371-1383

Johnson MW (1939) The correlation of water movement and dispersal of pelagic larval stages of certain littoral animals, especially the sand crab Emerita. J Mar Res 2: $236-245$

Johnson WM (1960) The offshore drift of larvae of the California spiny lobster, Panulirus interruptus. Calif Coop Ocean Fish Invest 7:147-161

Johnson MW (1971) The pallinurid and scyllarid lobster larvae of the tropical eastern Pacific and their distribution as related to the prevailing hydrography. Bull Scripps Inst Oceangr 19:1-36

Johnson WM (1974) On the dispersal of lobster larvae into the East Pacific Barrier (Decapoda, Palinuridae). Fish Bull US 72:639-647

Johst K, Brandl R (1997) Evolution of dispersal: the importance of the temporal order of reproduction and dispersal. Proc R Soc Lond B 264:23-30

Jokiel PL (1989) Rafting of reef corals and other organisms at Kwajalein Atoll. Mar Biol 101:483-493

Jones GP (1997) Relationships between recruitment and postrecruitment processes in lagoonal populations of two coral reef fishes. J Exp Mar Biol Ecol 213:231-246

Jonsson PR, André C, Lindegarth M (1991) Swimming behaviour of marine bivalve larvae in a flume boundary-layer flow: evidence for near-bottom confinement. Mar Ecol Prog Ser 79:67-76

King RB, Lawson R (1997) Microevolution in island water snakes. BioScience 47:279-286

Knight-Jones EW (1953) Laboratory experiments on gregariousness during settling in Balanus balanoides and other barnacles. J Exp Biol 30:584-599

Knowlton N, Keller BD (1986) Larvae which fall far short of their potential: highly localized recruitment in an alpheid shrimp with extended larval development. Bull Mar Sci 39:213-223

Knudsen J (1950) Egg capsule size and development of some marine prosobranchs from tropical West Africa. Atlantide Rep 1:85-130

Koehn RK, Newell REI, Immermann F (1980) Maintenance of an aminopeptidase allele frequency cline by natural selection. Proc Natl Acad Sci USA 77:5385-5389

Kohn AJ (1961) Studies on spawning behavior, egg masses, and larval development in the gastropod genus Conus. I. Observations on nine species in Hawaii. Pacif Sci 15: $163-180$

Krug PJ (1998) Poecilogony in an estuarine opisthobranch: planktotrophy, lecithotrophy, and mixed clutches in a population of the ascoglossan Alderia modesta. Mar Biol 132: $483-494$
Kruuk LEB, Gilchrist JS (1997) Mechanisms maintaining species differentiation: predator-mediated selection in a Bombina hybrid zone. Proc Roy Soc Lond B 264:105-110

Lambert WJ, Iodd CD, Hardege JD (1997) Partial characterization and biological activity of a metamorphic inducer of the dorid nudibranch Adalaria proxima (Gastropoda: Nudibranchia). Invertebr Biol 116:71-81

Lasker HR, Kim K (1996) Larval development and settlement behavior of the gorgonian coral Plexaura kuna (Lasker, Kim and Coffroth). J Exp Mar Biol Ecol 207:161-175

Lebour MV (1937) The eggs and larvae of the British prosobranchs with special reference to those living in the plankton. J Mar Biol Assoc UK 22:105-166

Lee CE, Strathmann RR (1998) Scaling of gelatinous clutches: effects of siblings' competition for oxygen on clutch size and parental investment per offspring. Amer Nat 151: 295-310

Lessios HA, Kessing BD, Robertson DR (1998) Massive gene flow across the world's most potent marine biogeographic barrier. Proc Roy Soc Lond B 265:583-588

Letcher BH, Rice JA, Crowder LB, Rose KA (1996) Variability in survival of larval fish: disentangling components with a generalized individual-based model. Can J Fish Aquat Sci 53:787-801

Levin LA, Bridges TS (1995) Pattern and diversity in reproduction and development. In: McEdward L (ed) Ecology of marine invertebrate larvae. CRC Press, Boca Raton, FL, p $1-48$

Levinton JS (1995) Marine biology. Oxford University Press, New York, p 109-111

Lima GM, Lutz RA (1990) The relationship of larval shell morphology to mode of development in marine prosobranch gastropods. J Mar Biol Assoc UK 70:611-637

Lindquist N, Hay ME (1995) Can small rare prey be chemically defended? The case for marine larvae. Ecology 76 : $1347-1358$

Lindquist N, Hay ME (1996) Palatability and chemical defense of marine invertebrate larvae. Ecol Monogr 66:431-450

Linhart YB, Grant MC (1996) Evolutionary significance of local genetic differentiation in plants. Annu Rev Ecol Syst 27:237-277

Litvak MK, Leggett WC (1992) Age and size-selective predation on larval fishes: the bigger-is-better hypothesis revisited. Mar Ecol Prog Ser 81:13-24

Lloyd JE (1975) Aggressive mimicry in Photuris fireflies: signal repertoires by femmes fatales. Science 187:452-453

Luo J, Brandt SB, Klebasko MJ (1996) Virtual reality of planktivores: a fish's perspective of prey size selection. Mar Ecol Prog Ser 140:271-283

Macdonald JM, Shields JD, Zimmer-Faust RK (1988) Acute toxicities of eleven metals to early life-history stages of the yellow crab Cancer anthonyi. Mar Biol 98:201-207

MacGinitie GE (1934) The egg-laying activities in the sea hare Tethys californicus (Cooper). Biol Bull 67:300-303

Martel A, Chia FS (1991) Drifting and dispersal of small bivalves and gastropods with direct development. J Exp Mar Biol Ecol 150:131-147

Mayr E (1970) Populations, species, and evolution. Harvard University Press, Cambridge, MA

McEdward LR (1992) Morphology and development of a unique type of pelagic larva in the starfish Pteraster tesseIatus (Echinodermata: Asteroidea). Biol Bull 182:177-187

McEdward LR (1995) Evolution of pelagic direct development in the starfish Pteraster tesselatus (Asteroidea: Velatida). Biol J Linn Soc 54:299-327

McEdward LR, Janies DA (1993) Life cycle evolution in asteroids: what is a larva? Biol Bull 184:255-268 
McEdward LR, Janies DA (1997) Relationships among development, ecology, and morphology in the evolution of echinoderm larvae and life cycles. Biol J Linn Soc 60:381-400

McHugh D (1993) A comparative study of reproduction and development in the polychaete family Terebellidae. Biol Bull 185:153-167

McHugh D, Rouse GW (1998) Life history evolution of marine invertebrates: new views from phylogenetic systematics. Trends Ecol Evol 13:182-186

Medeiros-Bergen DE, Ebert TA (1995) Growth, fecundity and mortality rates of two intertidal brittlestars (Echinodermata: Ophiuroidea) with contrasting modes of development. J Exp Mar Biol Ecol 189:47-64

Medernach L (1995) Rôle du cocon muqueux dans la protection des larves de Eupolymnia nebulosa (Annélide Polychète). Rapport de Maîtrise (Ecologie marine) Laboratoire Arago

Menge BA (1974) Effect of wave action and competition on brooding and reproductive effort in the sea star Leptasterias hexactis. Ecology 55:84-93

Middaugh DP, Floyd G (1978) The effect of prehatch and posthatch exposure to cadmium on salinity tolerance of larval grass shrimp, Palaemonetes pugio. Estuaries 1 $123-125$

Mileikosvky SA (1971) Types of larval development in marine bottom invertebrates, their distribution and ecological significance: a re-evaluation. Mar Biol 10:193-213

Mileikovsky SA (1974) On predation of pelagic larvae and early juveniles of marine bottom invertebrates by adult benthic invertebrates and their passing alive through their predators. Mar Biol 26:303-311

Mileikovsky SA (1975) Types of larval development in Littorinidae (Gastropoda: Prosobranchia) of the world ocean. and ecological patterns of their distribution. Mar Biol 30: $129-135$

Miller SE (1993) Larval period and its influence on post-larval life history: comparison of lecithotrophy and facultative planktotrophy in the aeolid nudibranch Phestilla sibogae. Mar Biol 117:635-645

Moksnes PO, Pihl L, van Montfrans J (1998) Predation on postlarvae and juveniles of the shore crab Carcinus maenas: importance of shelter, size and cannibalism. Mar Ecol Prog Ser 166:211-225

Mooi R, David B (1993) Ontogeny and origin of the brooding system in Antarctic urechinid sea urchins (Holasteroida). Zoomorphology 113:69-78

Mooi R, David B (1996) Phylogenetic analysis of extreme morphologies: deep-sea holasteroid echinoids. J Nat Hist 30: 913-953

Moore PH (1977) Additions to the littoral fauna of Rockall with descriptions of Araeolaimus penelope sp. nov. (Nematoda: Axonolaimidae). J Mar Biol Assoc UK 57:191-200

Moran AL (in press) Intracapsular feeding by embryos of the gastropod genus Littorina. Biol Bull

Morgan SG (1995a) Life and death in the plankton: larval mortality and adaptation. In: McEdward L (ed) Ecology of marine invertebrate larvae. CRC Press, Boca Raton, FL, p 279-321

Morgan SG (1995b) The timing of larval release. In: McEdward L (ed) Ecology of marine invertebrate larvae. CRC Press, Boca Raton, FL, p 157-191

Morgan SG, Christy JH (1997) Planktivorous fishes as selective agents for reproductive synchrony. J Exp Mar Biol Ecol 209:89-101

Morrison G (1971) Dissolved oxygen requirements for embryonic and larval development of the hardshell clam Mercenaria mercenaria. J Fish Res Bd Can 28:379-381
Morritt D. Spicer JI (1996) Developmental ecophysiology of the beachflea Orchestia gammarellus (Pallas) (Crustacea: Amphipoda). I. Female control of the embryonic environment. J Exp Mar Biol Ecol 207:191-203

Morse DE, Morse ANC, Raimondi PT, Hooker N (1994) Morphogen-based chemical flypaper for Agaricia humilis coral larvae. Biol Bull 186:172-181

Naylor JR, McShane PE (1997) Predation by polychaete worms on larval and post-settlement abalone Haliotis inis (Mollusca: Gastropoda). J Exp Mar Biol Ecol 214:283-290

Newman WA, Ross A (1977) A living Tesseropora (Cirripedia Balanomorpha) from Bermuda and the Azores: first records from the Atlantic since the Oligocene. Trans $S$ Diego Soc Nat Hist 18:207-216

Nielsen C (1998) Origin and evolution of animal life cycles. Biol Rev 73:125-155

Obrebski S (1979) Larval colonizing strategies in marine benthic invertebrates. Mar Ecol Prog Ser 1:293-300

$\mathrm{O}^{\prime}$ Connor NJ (1991) Flexibility in timing of the metamorphic molt by fiddler crab megalopae Uca pugilator. Mar Ecol Prog Ser 68:243-247

O'Foighil D (1989) Planktotrophic larval development is associated with a restricted geographic range in Lasaea, a genus of brooding, hermaphroditic bivalves. Mar Biol 103 349-358

Olson $\mathrm{MH}$ (1996) Predator-prey interactions in size-structured fish communities: implications of prey growth. Oecologia 108:757-763

Olson RR (1983) Ascidian-Prochloron symbiosis: the role of larval photoadaptations in midday larval release and settlement. Biol Bull 165:221-240

Olson RR, McPherson R (1987) Potential vs. realized larval dispersal: fish predation on larvae of the ascidian Lissoclinum patella (Gottschaldt). J Exp Mar Biol Ecol 110: $245-256$

Olson RR, Olson MH (1989) Food limitation of planktotrophic marine invertebrate larvae: does it control recruitment success? Annu Rev Ecol Syst 20:225-247

Olson RR, Cameron JL, Young CM (1993) Larval development (with observations on spawning) of the pencil urchin Phyllacanthus imperialis: a new intermediate larval form? Biol Bull 185:77-85

Orellana MC, Cancino JM (1991) Effects of delaying larval settlement on metamorphosis and early colonial growth in Celleporella hyalina (Bryozoa: Cheilostomata). Bull Soc Sci Nat Ouest Fr Mem 1:309-316

Orians GH, Janzen DH (1974) Why are embryos so tasty? Am Nat 108:581-592

Osman RW, Whitlatch RB (1996) Processes affecting newlysettled juveniles and the consequences to subsequent community development. Invertebr Reprod Dev 30 $217-225$

Page LR (1994) The ancestral gastropod larval form is best approximated by hatching-stage opisthobranch larvae evidence from comparative developmental studies. In: Wilson WH Jr, Stricker SA, Shinn GL (eds) Reproduction and development of marine invertebrates. The John Hopkins University Press, Baltimore, p 206-223

Palmer AR (1990) Predator size, prey size, and the scaling of vulnerability: hatchling gastropods vs. barnacles. Ecology $71: 759-775$

Palumbi SR (1995) Using genetics as an indirect estimator of larval dispersal. In: McEdward L (ed) Ecology of marine invertebrate larvae. CRC Press, Boca Raton, FL, p 369-387

Parsons KE (1996) The genetic effects of larval dispersal depend on spatial scale and habitat characteristics. Mar Biol 126:403-414 
Parsons KE (1998) The role of dispersal ability in the phenotypic differentiation and plasticity of two marine gastropods, II. Growth. J Exp Mar Biol Ecol 221. 1-25

Pawlik JR (1990) Natural and artificial induction of metamorphosis of Phragmatopoma lapidosa californica (Polychaeta: Sabellariidae), with a critical look at the effects of bioactive compounds on marine invertebrate larvae. Bull Mar Sci 46:512-536

Pawlik JR, Kernan MR, Molinski TF, Harper MK, Faulkner JD (1988) Defensive chemicals of the Spanish Dancer nudibranch Hexabranchus sanguineus and its egg ribbons: macrolides derived from a sponge diet. J Exp Mar Biol Ecol 1 19:99-109

Peacock MM, Smith AT (1997) The effect of habitat fragmentation on dispersal patterns, mating behavior, and genetic variation in a pika (Ochotona princeps) metapopulation. Oecologia 112:524-533

Pearce CM, Scheibling RE (1990) Induction of settlement and metamorphosis in the sand dollar Echinarachnius parma: evidence for an adult-associated factor. Mar Biol 107: $363-369$

Pechenik JA (1978) Adaptations to intertidal development: studies on Nassarius obsoletus. Biol Bull 154:282-291

Pechenik JA (1979) Role of encapsulation in invertebrate life histories. Am Nat 114:859-870

Pechenik JA (1980) Growth and energy balance during the larval lives of three prosobranch gastropods. J Exp Mar Biol Ecol 44:1-28

Pechenik JA (1982) Ability of some gastropod egg capsules to protect against low-salinity stress. J Exp Mar Biol Ecol 63: 195-208

Pechenik JA (1983) Egg capsules of Nucella lapillus (L.) protect against low-salinity stress. J Exp Mar Biol Ecol 71 : $165-179$

Pechenik JA (1986a) The encapsulation of eggs and embryos by molluscs: an overview. Am Malac Bull 4:165-172

Pechenik JA (1986b) Field evidence for delayed metamorphosis of larval gastropods: Crepidula plana, Crepidula fornicata, and Bittium alternatum (Say). J Exp Mar Biol Ecol 97. $313-319$

Pechenik JA (1987) Environmental influences on larval survival and development. In: Giese AC, Pearse JS, Pearse VB (eds) Reproduction of marine invertebrates. IX. Blackwell Scientific, Palo Alto, CA, p 551-608

Pechenik JA (1990) Delayed metamorphosis by larvae of benthic marine invertebrates: Does it occur? Is there a price to pay? Ophelia 32:63-94

Pechenik JA, Cerulli TR (1991) Influence of delayed metamorphosis on survival, growth, and reproduction of the marine polychaete Capitella sp. I. J Exp Mar Biol Ecol 151 $17-27$

Pechenik JA, Heyman (1987) Using $\mathrm{KCl}$ to determine size at competence for larvae of the marine gastropod Crepidula fornicata (L.). J Exp Mar Biol Ecol 112:27-38

Pechenik JA, Miller DC (1983) Increased susceptibility to No. 2 fuel ail coincident with initiation of particle feeding in developing mud snails, llyanassa obsoleta. Estuaries 6: 237242

Pechenik JA, Rittschof D, Schmidt AR (1993) Influence of delayed metamorphosis on survival and growth of juvenile barnacles Balanus amphitrite. Mar Biol 115:287-294

Pechenik JA, Estrella MS, Hammer K (1996a) Food limitation stimulates metamorphosis of competent larvae and alters postmetamorphic growth rate in the marine prosobranch gastropod Crepidula fornicata. Mar Biol 127:267-275

Pechenik JA, Hammer K, Weise C (1996b) The effect of starvation on acquisition of competence and post-metamor- phic performance in the marine prosobranch gastropod Crepidula fornicata (L.). J Exp Mar Biol Ecol 199:137-152

Pechenik JA, Wendt DE, Jarrett JN (1998) Metamorphosis is not a new beginning. BioScience 48:901-910

Pennington JT, Emlet RB (1986) Ontogenetic and diel vertical migration of a planktonic echinoid larva, Dendraster excentricus (Eschscholtz): occurrence, causes, and probable consequences. J Exp Mar Biol Ecol 104:69-95

Pepin P, Shears TH (1995) Influence of body size and alternate prey abundance on the risk of predation to fish larvae. Mar Ecol Prog Ser 128:279-285

Perron FE (1981) Larval biology of six species of the genus Conus (Gastropoda: Toxoglossa) in Hawaii, USA Mar Biol $61: 215-220$

Perron FE, Corpuz GC (1982) Costs of parental care in the gastropod Conus pennaceus: age-specific changes and physical constraints. Oecologia 55:319-324

Peters LD, Livingstone DR (1996) Antioxidant enzyme activities in embryologic and early larval stages of turbot. J Fish Biol 49.986-997

Petersen JK, Svane I (1995) Larval dispersal in the ascidian Ciona intestinalis (L.). Evidence for a closed population. $J$ Exp Mar Biol Ecol 186:89-102

Peterson MA (1996) Long-distance gene flow in the sedentary butterfly, Euphilotes enoptes (Lepidoptera: Lycaenidae). Evolution 50:1.990-1999

Plaut I, Borut A, Spira ME (1995) Growth and metamorphosis of Aplysia oculifera larvae in laboratory culture. Mar Biol 122:425-430

Pollock DE (1992) Palaeoceanography and speciation in the spiny lobster genus Panulirus in the Indo-Pacific. Bull Mar Sci 51:135-146

Ponder W, Lindberg DR (1997) Towards a phylogeny of gastropod molluscs - analysis using morphological characters. Zool J Linn Soc 119:83-265

Poulin E, Féral JP (1996) Why are there so many species of brooding antarctic echinoids? Evolution 50:820-830

Price PW (1984) Insect ecology, 2nd edn. John Wiley \& Sons, New York, p 261-303

Prince JD, Seller TL, Ford WB, Talbot SR (1987) Experimental evidence for limited dispersal of haliotid larvae (genus Haliotis; Mollusca: Gastropoda). J Exp Mar Biol Ecol 106: 243-263

Pusey A, Wolf $M$ (1996) Inbreeding avoidance in animals Trends Ecol Evol 11:201-206

Qian PY, Pechenik JA (1998) Effects of larval starvation and delayed metamorphosis on juvenile survival and growth of the tube-dwelling polychaete Hydroides elegans (Haswell). J Exp Mar Biol Ecol 227:169-185

Qiu JW, Qian PY (1997) Combined effects of salinity, temperature and food on early development of the polychaete Hydroides elegans. Mar Ecol Prog Ser 152:79-88

Raff RA (1987) Constraint, flexibility, and phylogenetic history in the evolution of direct development in sea urchins. Dev Biol 119:6-19

Raff RA (1996) The shape of life: genes, development, and the evolution of anjmal form. University Chicago Press, Chicago

Rawlings TA (1990) Associations between egg capsule morphology and predation among populations of the marine gastropod, Nucella emarginata. Biol Bull 179:312-325

Rawlings TA (1994) Encapsulation of eggs by marine gastropods: effect of variation in capsule form on the vulnerability of embryos to predation. Evolution 48:1301-1313

Rawlings TA (1996) Shields against ultraviolet radiation: an additional protective role for the egg capsules of benthic marine gastropods. Mar Ecol Prog Ser 136:81-95 
Ray-Culp M, Davis M, Stoner AW (1997) The micropredators of settling and newly settled queen conch (Strombus gigas Linnaeus). J Shellfish Res 16:423-428

Reid DG (1989) The comparative morphology, phylogeny and evolution of the gastropod family Littorinidae. Phil Trans R Soc Lond B 324:1-110

Reinfelder JR, Fisher NS (1994) The assimilation of elements ingested by marine planktonic bivalve larvae. Limnol Oceanogr 39:12-20

Rex MA, Warén A (1982) Planktotrophic development in deep-sea prosobranch snails from the western North Atlantic. Deep-Sea Res 29:171-184

Rice JA, Miller TJ, Rose KA, Crowder LB, Marschall EA, Trebitz AS, DeAngelis DL (1993) Growth rate variation and larval survival: inferences from an individual-based size-dependent predation model. Can J Fish Aquat Sci 50: $133-142$

Richmond CE, Woodin SA (1996) Short-term fluctuations in salinity: effects on planktonic invertebrate larvae. Mar Ecol Prog Ser 133:167-177

Richter G (1973) Field and laboratory observations on the diurnal vertical migration of marine gastropod larvae. Neth J Sea Res 7:126-134

Ridley M (1996) Evolution, 2nd edn. Blackwell Scientific, Palo Alto, CA, p 639-662

Rieger RM (1994) The biphasic life cycle-a central theme of metazoan evolution. Am Zool 34:484-491

Ringwood AH (1989) Accumulation of cadmium by larvae and adults of an Hawaiian bivalve, Isognomon californicum, during chronic exposure. Mar Biol 102:499-504

Rivest BR (1983) Development and the influence of nurse egg allotment on hatching size in Searlesia dira (Reeve, 1846) (Prosobranchia: Buccinidae). J Exp Mar Biol Ecol 69: $217-241$

Rossi SS, Anderson JW (1976) Toxicity of water soluble fractions of No. 2 fuel oil and South Louisiana Crude Oil to selected stages in the life history of the polychaete, Neanthes arenaceodentata. Bull Environ Contam Tox 16:18-24

Roughgarden J, Gaines S, Possingham H (1988) Recruitment dynamics in complex life cycles. Science 241:1460-1466

Rouse GW, Fitzhugh K (1994) Broadcasting fables: is external fertilization really primitive? Sex, size, and larvae in sabellid polychaetes. Zool Scr 23:271-312

Rumrill SS (1990) Natural mortality of marine invertebrate larvae. Ophelia 32:163-198

Saccheri IJ, Brakefield PM, Nichols RA (1996) Severe inbreeding depression and rapid fitness rebound in the butterfly Bicyclus anynana (Satyridae). Evolution 50: 2000-2013

Sakai AK, Weller SG, Cheng ML, Chou SY, Tasanont C (1997) Evolution of gynodioecy and maintenance of females: the role of inbreeding depression, outcrossing rates, and resource allocation in Schiedea adamantis (Caryophyllaceae). Evolution 51:724-736

Sanders JG, Osman RW, Riedel GF (1989) Pathways of arsenic uptake and incorporation in estuarine phytoplankton and the filter-feeding invertebrates Eurytemora affinis, Balanus improvisus and Crassostrea virginica. Mar Biol 103:319-325

Scheltema AH (1969) Pelagic larvae of New England gastropods. IV. Anachis translirata and Anachis avara. Vie Milieu 20:95-103

Scheltema RS (1961) Metamorphosis of the veliger larvae of Nassarius obsoletus (Gastropoda) in response to bottom sediment. Biol Bull 120:92-109

Scheltema RS (1962) Pelagic larvae of New England intertidal gastropods. I. Nassarius obsoletus Say and Nassarius vibex Say. Trans Am Microsc Soc 81:1-11
Scheltema RS (1967) The relationship of temperature to the larval development of Nassarius obsoletus (Gastropoda). Biol Bull 132:253-265

Scheltema RS (1971) Larval dispersal as a means of genetic exchange between geographically separated populations of shallow-water benthic marine gastropods. Biol Bull 140: $284-322$

Scheltema RS (1986) On dispersal and planktonic larvae of benthic invertebrates: an eclectic overview and summary of problems. Bull Mar Sci 39:290-322

Scheltema RS (1995) The relevance of passive dispersal for the biogeography of Caribbean mollusks. Am Malac Bull 11:99-115

Scheltema RS, Scheltema AH (1963) Pelagic larvae of New England intertidal gastropods. II. Anachis avara. Hydrobiologia 22:85-91

Scheltema RS, Scheltema AH (1965) Pelagic larvae of New England intertidal gastropods. III. Nassarius trivittatus. Hydrobiologia 25:321-329

Scheltema RS, Williams IP, Lobel PS (1996) Retention around and long-distance dispersal between oceanic islands by planktonic larvae of benthic gastropod Mollusca. Am Malac Bull 12:67-75

Scudiero R, Capasso C, Carginale V, Filosa S, Capasso A, Parisi $E$ (1996) Isolation and characterisation of zinc-binding proteins distinct from metallothionein from the eggs of the sea urchin Strongylocentrotus intermedius. Mar Biol 126:225-230

Selck H, Forbes VE, Forbes TL (1998) Toxicity and toxicokinetics of cadmium in Capitella sp. I: relative importance of water and sediment as routes of cadmium uptake. Mar Ecol Prog Ser 164:167-178

Sepkoski JJ Jr (1996) Patterns of Phanerozoic extinction: a perspective from global data bases. In: Walliser $\mathrm{OH}$ (ed) Global events and event stratigraphy. Springer, Berlin, p 35-51

Sewell MA (1996) Mortality of pentactulae during intraovarian brooding in the apodid sea cucumber Leptosynapta clarki. Biol Bull 190:188-194

Shanks AL (1995) Mechanisms of cross-shelf dispersal of larval invertebrates. In: McEdward L (ed) Ecology of marine invertebrate larvae. CRC Press, Boca Raton, FL, p 369-387

Shubin N, Tabin D, Carroll S (1997) Fossils, genes and the evolution of animal limbs. Nature 388:639-648

Shuto T (1974) Larval ecology of prosobranch gastropods and its bearing on biogeography and paleontology. Lethaia 7 239-256

Slatkin M (1985) Gene flow in natural populations. Annu Rev Ecol Syst 16:393-430

Smith AB, Jeffery CH (1998) Selectivity of extinction among sea urchins at the end of the Cretaceous period. Nature 392:69-71

Sousa WP (1993) Size-dependent predation on the salt marsh snail Cerithidea californica Haldeman. J Exp Mar Biol Ecol 166:19-37

Spight TM (1.975) Factors extending gastropod embryonic development and their selective cost. Oecologia 21:1-16

Spight TM (1976) Hatching size and the distribution of nurse eggs among prosobranch embryos. Biol Bull 150:491-499

Spight TM (1977) Do intertidal snails spawn in the right places? Evolution 31:682-691

Stoner AW, Ray M, Glazer RA, McCarthy KJ (1996) Metamorphic responses to natural substrata in a gastropod larva: decisions related to postlarval growth and habitat preference. J Exp Mar Biol Ecol 205:229-243

Stoner DS (1990) Recruitment of a tropical colonial ascidian: relative importance of pre-settlement vs. post-settlement processes. Ecology 71:1682-1690 
Storfer A, Sih A (1998) Gene flow and ineffective antipredator behavior in a stream-breeding salamander. Evolution 52: $558-565$

Stowe MK, Tumlinson JH, Heath RR (1987) Chemical mimicry: bolas spiders emit components of moth prey species sex pheromones. Science 236:964-968

Strathmann MF (1987) Reproduction and development of marine invertebrates of the northern Pacific coast: data and methods for the study of eggs, embryos, and larvae. University Washington Press, Seattle

Strathmann RR (1974) The spread of sibling larvae of sedentary marine invertebrates. Am Nat 108:29-44

Strathmann RR (1978) The evolution and loss of feeding larval stages of marine invertebrates. Evolution 32:894-906

Strathmann RR (1985) Feeding and nonfeeding larval development and life-history evolution in marine invertebrates. Annu Rev Ecol Syst 16:339-361

Strathmann RR (1986) What controls the type of larval development? Summary statement for the evolution session. Bull Mar Sci 39:616-622

Strathmann RR (1993) Hypotheses on the origins of marine larvae. Annu Rev Ecol Syst 24:89-117

Strathmann RR, Eernisse DJ (1994) What molecular phylogenies tell us about the evolution of larval forms. Am Zool 34:502-512

Strathmann RR, Strathmann MF (1982) The relationship between adult size and brooding in marine invertebrates. Am Nat 119:91-101

Strathmann RR, Branscomb ES, Vedder K (1981) Fatal errors in set as a cost of dispersal and the influence of intertidal flora on set of barnacles. Oecologia 48:13-18

Strathmann RR, Strathmann MF, Emson RH (1984) Does limited brood capacity link adult size, brooding, and simultaneous hermaphroditism? A test with the starfish Asterina phylactica. Am Nat 123:796-818

Struhsaker JW, Costlow JDJ (1968) Larval development of Littorina picta (Prosobranchia, Mesogastropoda), reared in the laboratory. Proc Malac Soc Lond 38:153-160

Sulkin SD, Van Heukelem WF, Kelly P (1983) Behavioral basis of depth regulation in hatching and post-larval stages of the mud crab Eurypanopeus depressus. Mar Ecol Prog Ser $11: 157-164$

Sulkin SD, Mojica E, McKeen GL (1996) Elevated summer temperature effects on megalopal and early juvenile development in the Dungeness crab, Cancer magister. Can J Fish Aquat Sci 53:2076-2079

Swalla BJ, Makabe KW, Satoh N, Jeffery WR (1993) Novel. genes expressed differentially in ascidians with alternate modes of development. Development 1 19:307-318

Tamburri MN, Zimmer-Faust RK (1996) Suspension-feeding: basic mechanisms controlling recognition and ingestion of larvae. Limnol Oceanogr 41:1188-1197

Thiriot-Quiévreux C (1980) Identification of some planktonic prosobranch larvae present off Beaufort, North Carolina. Veliger 23:1-9

Thorson G (1946) Reproduction and larval development of Danish marine bottom invertebrates. Meddr Kommn Danm Fishk-og Havunders (Ser Plankton) 4:1-523

Thorson G (1950) Reproductive and larval ecology of marine bottom invertebrates. Biol Rev 25:1-45

Thorson G (1961) Length of pelagic larval life in marine bottom invertebrates as related to larval transport by ocean currents, In: Sears $M$ (ed) Oceanography. American Association for the Advancement of Science, Washington, DC, p 455-473

Thorson $G$ (1966) Some factors influencing the recruitment and establishment of marine benthic communities. Neth $J$ Sea Res 3:267-293
Todd CD (1979) Reproductive energetics of two species of dorid nubidranchs with planktotrophic and lecithotrophic larval strategies. Mar Biol 53:57-68

Toomey BH, Epel D (1993) Multixenobiotic resistance in Urechis caupo embryos: protection from environmental toxins. Biol Bull 185:355-364

Toonen RJ, Pawlik JR (1994) Foundations of gregariousness Nature 370:511-512

Toonen RJ, Pawlik JR (1996) Settlement of the tube worm Hydroides dianthus (Polychaeta: Serpulidae) : cues for gregarious settlement. Mar Biol 126:725-733

Turon X, Vázquez E (1996) A non-swimming ascidian larva: Protostyela longicauda (Styelidae). Invertebr Biol 115: $331-342$

Underwood AJ (1974) On models for reproductive strategy in marine benthic invertebrates. Am Nat 108:874-878

Uriz MJ, Turon X, Becerro MA, Galera J (1996) Feeding deterrence in sponges. The role of toxicity, physical defenses, energetic contents, and life-history stage. J Exp Mar Biol Ecol 205:187-204

Valentine JW (1986) The Permian-Triassic extinction event and invertebrate developmental modes. Bull Mar Sci 39: $607-615$

Valentine JW, Jablonski D (1.982) Major determinants of the biogeographic pattern of the shallow-sea fauna. Bull Soc Geol Fr 24:893-899

Valentine JW, Jablonski D (1983) Speciation in the shallow sea: general patterns and biogeographic controls. In: Sims RW, Price $\mathrm{JH}$, Whalley PES (eds) Evolution, time and space: the emergence of the biosphere. Academic Press, New York, p 201-226

Vance RR (1973) On reproductive strategies in marine benthic invertebrates. Am Nat 197:339-352

Vermeij GJ (1978) Biogeography and adaptation: patterns of marine life. Harvard University Press, Cambridge, MA

Vermeij GJ (1982) Phenotypic evolution in a poorly dispersing snail after arrival of a predator. Nature 299:349-350

Wahle RA, Steneck RS (1992) Habitat restrictions in early benthic life: experiments on habitat selection and in situ predation with the American lobster. J Exp Mar Biol Ecol 157:91-114

Walters LJ, Wethey DS (1996) Settlement and early post-settlement survival of sessile marine invertebrates on topographically complex surfaces: the importance of refuge dimensions and adult morphology. Mar Ecol Prog Ser 137:161-171

Warén A (1996) Ecology and systematics of the north European species of Rissoa and Pusillina (Prosobranchia: Rissoidae). J Mar Biol Assoc UK 76:1013-1059

Watts R, Johnson MS, Black R (1990) Effects of recruitment on genetic patchiness in the urchin Echinometra mathael in Western Australia. Mar Biol 1.05:145-151

Weber JC, Epifanio CE (1996) Response of mud crab (Panopeus herbstiil megalopae to cues from adult habitat. Mar Biol 126:655-661

Wendt DE (1996) Effect of larval swimming duration on success of metamorphosis and size of the ancestrular lophophore in Bugula neritina (Bryozoa). Biol Bull 191:224-233

Wendt DE (1998) Effect of larval swimming duration on growth and reproduction of Bugula neritina (Bryozoa) under field conditions. Biol Bull 195:126-135

Weston DP (1990) Hydrocarbon bioaccumulation from contaminated sediment by the deposit-feeding polychaete Abarenicola pacifica. Mar Biol 107:159-169

Williams ST, Benzie JAH (1996) Genetic uniformity of widely separated populations of the coral reef starfish Linckia laevigata from the East Indian and West Pacific Oceans, revealed by allozyme electrophoresis. Mar Biol 126:99-107 
Wolpert L (1994) The evolutionary origin of development: cycles, patterning, privilege and continuity. Development 1994 (Suppl):79-84

Woods HA, DeSilets RL Jr (1997) Egg mass gel of Melanochlamys diomedea (Bergh) protects embryos from low salinity. Biol Bull 193:341-349

Woollacott RM, Pechenik JA, Imbalzano KM (1989) Effects of duration of larval swimming period on early colony development in Bugula stolonifera (Bryozoa: Cheilostomata). Mar Biol 102.57-63

Wray GA (1995) Evolution of larvae and developmental modes. In: McEdward L (ed) Ecology of marine invertebrate larvae. CRC Press, Boca Raton, FL, p 413-447

Wray GA, Raff RA (1991) Rapid evolution of gastrulation mechanisms in a sea urchin with lecithotrophic larvae. Evolution 45:1741-1750

Yamada SB (1989) Are direct developers more locally adapted than planktonic developers? Mar Biol 103:403-411

Yamaguchi M, Lucas JS (1984) Natural parthenogenesis, larval and juvenile development, and geographical distribution of the coral reef asteroid Ophidiaster granifer. Mar Biol 83:33-42

Yamashita Y, Tsuruta Y, Yamada $H$ (1996) Transport and settlement mechanisms of larval stone flounder, Karejus

Editorial responsibility: Lisa Levin (Contributing Editor),

La Jolla, California, USA bicoloratus, into nursery grounds. Fish Oceanogr 5 $194-204$

Young CM (1990) Larval predation by epifauna on temperate reefs: scale, power and the scarcity of measurable effects. Aust J Ecol 15:413-426

Young CM, Chia FS (1987) Abundance and distribution of pelagic larvae as influenced by predation, behavior, and hydrographic factors. In: Giese AC, Pearse JS, Pearse VB (eds) Reproduction of marine invertebrates. IX. Blackwell Scientific, Palo Alto, CA, p 385-463

Young CM, Gowan RF, Dalby J Jr, Pennachetti CA, Gagliardi D (1988) Distributional consequences of adhesive eggs and anural development in the ascidian Molgula pacifica (Huntsman, 1912). Biol Bull 174:39-46

Young ML (1977) The roles of food and direct uptake from water in the accumulation of zinc and iron in the tissues of the dogwhelk, Nucella lapillus (L.). J Exp Mar Biol Ecol 30: $315-325$

Yule AB, Crisp DJ (1983) Adhesion of cypris larvae of the barnacle, Balanus balanoides, to clean and arthropodin treated surfaces. J Mar Biol Assoc UK 63:261-271

Zimmer-Faust RK, Tamburri MN (1994) Chemical identity and ecological implications of a waterborne, larval settlement cue. Limnol Oceanogr 39:1075-1087

Submitted: February 12, 1998; Accepted: September 5, 1998 Proofs received from author(s): February 4, 1999 